\title{
Metabolic Regulation of Adipose Tissue Macrophage Function in Obesity and Diabetes
}

\author{
Mahesh Appari, ${ }^{1,2}$ Keith M. Channon, ${ }^{1,2}$ and Eileen McNeill ${ }^{1,2}$
}

\begin{abstract}
Significance: Obesity and diabetes are associated with chronic activation of inflammatory pathways that are important mechanistic links between insulin resistance (IR), type 2 diabetes (T2D), and cardiovascular disease pathogenesis. The development of these metabolic diseases is associated with changes in both the number and phenotype of adipose tissue macrophages (ATMs). Emerging lines of evidence have shown that ATMs release proinflammatory cytokines similar to classically activated M1 macrophages, which directly contribute to IR or T2D. In contrast, adipose tissue (AT) from lean healthy individuals contains macrophages with a less inflammatory M2 phenotype. Recent Advances: Recent research has shown that macrophage phenotype is linked to profound changes in macrophage cellular metabolism.

Critical Issues: This review focuses on the role of macrophages in AT inflammation and obesity, and the metabolic changes in macrophage function that occur with activation that underpin their role in the pathogenesis of IR and T2D. We highlight current targets for altering macrophage metabolism from both within the field of metabolic disease and AT biology and more widely within inflammatory biology.

Future Directions: As our knowledge of macrophage metabolic programming in AT builds, there will be increasing scope for targeting this aspect of macrophage biology as a therapeutic strategy in metabolic diseases. Antioxid. Redox Signal. 29, 297-312.
\end{abstract}

Keywords: obesity, redox signaling, immunometabolism, macrophages, diabetes

Introduction

$\mathbf{O}$ BESITY AND TYPE 2 DIABETES (T2D) are global health problems causing substantial morbidity, early mortality, and a massive health economic burden. The World Health Organization global health observatory estimated that $10.8 \%$ of men and $14.9 \%$ of women were obese with a body mass index (BMI) of 30 or more in 2014. Human cohort studies indicate that multiple risk factors coexist in the metabolic syndrome, including obesity, insulin resistance (IR), elevated blood pressure, impaired glucose tolerance, and dyslipidemia. These patients are at increased risk for developing T2D and manifest vascular disease and increased risk for cardiovascular events and mortality (25). The metabolic consequences of adipose tissue (AT) dysfunction are more important factors in the development of cardiovascular risk in T2D patients rather than other markers of obesity such as BMI, waist circumference, and intraabdominal fat (26). Indeed, intervention studies suggest that even a modest $(5 \%)$ weight loss, achieved by low-calorie diet, substantially improves metabolic functions in AT, liver and muscle insulin sensitivity, and pancreatic $\beta$-cell function (61), suggesting that changes in AT biology and metabolism are critical regulators of disease pathogenesis in obesity and T2D.

IR is central to the adverse pathology linking obesity to T2D. IR can cause T2D, in particular, when pancreatic $\beta$-cell dysfunction emerges, which can no more be compensated by adequate insulin production. Insulin produced by pancreatic $\beta$-cells lowers blood glucose through insulin receptor activation in various cell types such as adipocytes, myocytes, and

\footnotetext{
${ }^{1}$ Division of Cardiovascular Medicine, British Heart Foundation Centre for Research Excellence, John Radcliffe Hospital, University of Oxford, Oxford, United Kingdom.

${ }^{2}$ Wellcome Trust Centre for Human Genetics, University of Oxford, Oxford, United Kingdom.

(C) Mahesh Appari et al., 2017; Published by Mary Ann Liebert, Inc. This Open Access article is distributed under the terms of the Creative Commons License (http://creativecommons.org/licenses/by/4.0), which permits unrestricted use, distribution, and reproduction in any medium, provided the original work is properly cited.
} 
hepatocytes to increase their glucose uptake. Moreover, insulin inhibits glucagon secretion by pancreatic $\alpha$-cells (via glycogenolysis and gluconeogenesis) (4). When IR occurs, downstream insulin signaling is impaired (as evidenced by, for example, reduced Akt phosphorylation), and/or directed via pathways that may lead to activation of stress pathways, such as the p38 MAP kinase. IR can be caused by many factors at a cellular level such as endoplasmic reticulum (ER) stress, oxidative stress, hypoxia, dysregulation of lipid homeostasis, and mitochondrial dysfunction. However, obesity is increasingly recognized as a major contributor to IR (19).

An association between obesity and inflammation was first identified in the 1960s (56). In obese individuals, systemic inflammation is indicated by elevated circulating levels of proinflammatory cytokines such as tumor necrosis factor alpha $(\mathrm{TNF}-\alpha)(51)$, and increased production of this proinflammatory cytokine by ATs (41). More recent studies have highlighted macrophages resident in ATs as a principal source for this inflammatory signature (103). This chronic metabolic inflammation (metainflammation or metaflammation) and metabolic dysfunction contribute to cardiovascular disease risk and pathogenesis in patients with obesity or T2D. Metaflammation is evident both systemically and in specific metabolic organs such as AT, liver, muscle, pancreas, brain, and gut.

Metaflammation is postulated to drive the transition toward the metabolic syndrome and T2D [reviewed in Ref. $(76,87)$ ]. Obese individuals exhibit an elevated number of circulating leukocytes, these cells show an activated proinflammatory phenotype with enhanced expression of macrophage migration inhibitory factor (MIF), TNF- $\alpha$, interleukin-6 (IL-6), and matrix metallopeptidase 9 (32). AT in these individuals has increased macrophage infiltration as body mass and adiposity increase $(103,106)$. Although a host of changes are seen systemically in obesity, the macrophage population resident in AT depots and other key sites of metabolic regulation appear to be key players, impacting disease progression not just through their number but also through alterations in their activation state. In this review, we discuss the role of macrophages in obesity and T2D. We focus on how cellular metabolism is altered in macrophages with different activation status, and describe how altered macrophage metabolism may impact on inflammation in diabetes and obesity.

\section{Adipose Tissue and Obesity}

AT, composed of adipocytes (specialized mesenchymal cells), also contains several other cell types such as stromal vascular cells, endothelial cells, fibroblasts, macrophages, and other leukocytes. The three types of AT, white, brown, and beige or brite (brown-like-in-white), are classified according to the origin and function of constituent cells. Brown adipose tissue (BAT) metabolizes lipids to generate heat (thermogenesis) in response to cold and $\beta$-adrenergic stimulation (36). BAT induces nonshivering thermogenesis by expressing mitochondrial protein, uncoupling protein 1 (UCP1) [reviewed in Ref. (36)]. The white adipose tissue (WAT) depot and its expansion (via adipocyte hyperplasia and hypertrophy) are considered as important to obesity and IR. There are two major types of WAT namely visceral AT (VAT), present in abdominal cavity and mediastinum, and subcutaneous AT in the hypodermis. AT location and its effect on metabolic function vary because of the differential gene expression patterns of the various depots [reviewed in Ref. (10) (86)]. For example, obese (high-fat-diet [HFD]-fed) sarcolipin deficient mice had shown depot-specific increase in AT inflammation and remodeling by expressing higher levels of the proinflammatory cytokines IL-6, IL- $1 \beta$, and $\mathrm{TNF}-\alpha$ in the epididymal fat rather than inguinal fat (59). These gene expression patterns are well correlated with macrophage infiltration and inflammatory activation. Human cohort studies demonstrate that VAT is strongly associated with glucose intolerance and IR (84). BAT is responsible for energy expenditure in thermogenesis against cold, and short-term cold exposure increases BAT activity resulting in accelerated clearance of plasma triglyceride (TG)-rich lipoproteins (5); [reviewed in Ref. (36)].

AT stores free fatty acid (FFA) after excess food intake, wherein elevated plasma FFA enters the adipocytes, and is transformed and stored as TGs. During the fasting stage, adipocytes release FFA to balance energy status (fuelling other organs) through lipogenesis and lipolysis. FFA binds to toll-like receptor 4 (TLR4) and activates a proinflammatory response, resulting in accumulation of adipose tissue macrophages (ATMs) $(18,94)$. The liver is a key organ in glucose homeostasis, with adipocyte-released FFA accumulating in the liver, resulting in fatty liver disease. Elevated FFAs are associated with IR in obese patients with T2D [reviewed in Ref. (7)].

In addition to metabolic functions, AT acts as an endocrine organ. Adipocytes in AT secrete hormones (adipokines or adipocytokines) such as leptin, adiponectin, and resistin along with retinol binding protein 4 and secreted frizzled-related protein 5 (Sfrp5), which exhibit endocrine or paracrine functions and are important in maintaining energy homeostasis (16, 88, 100). Sfrp5 is an anti-inflammatory adipokine expressed mainly in the adipocytes of WAT. HFD-fed Sfrp5-deleted mice exhibited accumulation of macrophages (F4/80 and CD68), c-Jun NH2-terminal kinase (JNK) activation, an increase in proinflammatory mediators (TNF- $\alpha$, IL-6, monocyte chemotactic protein-1 (MCP-1), severe glucose intolerance, and hepatic steatosis (79). Adipocytes also secrete chemokines such as MCP-1 and leukotriene B4 (Ltb4), a potent leukocyte chemoattractant and activator [reviewed in Ref. (68)]. Leukotrienes (LTs) are potent proinflammatory mediators in AT and cause IR. Inhibition of 5-lipoxygenase, an enzyme involved in the biosynthesis of LTs, in obese (HFD-fed) mice protects from IR by reduced AT macrophages and T cell infiltration (71). Adipokines exert their function on metabolic organs such as liver, skeletal muscle, pancreas, and the cardiovascular system. Adiponectin, which exerts anti-inflammatory functions, regulates uptake of FFA by muscle and WAT and decreases hepatic glucose production (7). Adiponectin also regulates glucose homeostasis and IR. In the presence of excess nutrients, the adiponectin receptor is downregulated by the activation of JNK pathway by TNF- $\alpha$ and IL-6 and oxidative stress (17).

\section{Cellular Events Associated with Metaflammation and Obesity}

Recent studies have revealed some of the cellular mechanisms responsible for the activation of inflammatory pathways in obesity and T2D. Obesity is associated with AT remodeling, which includes chronic low-grade activation of inflammation of AT and increased ATM infiltration, adipocyte hypertrophy, 
and increase in angiogenesis and extracellular matrix $(27,76)$. Adipocyte hypertrophy causes rupturing of adipocytes, resulting in increased local inflammatory cell accumulation, including macrophages, $\mathrm{T}$ cells, and altered production of adipokines (Fig. 1).

In humans, FFAs induce IR in muscle by initial inhibition of glucose transport followed by reduction in muscle glycogen synthesis and oxidation (85). FFAs can also induce IR by inhibiting glucose transport activity, which may be a consequence of decreased insulin receptor substrate-1 (IRS1)-mediated phosphatidylinositol 3-kinase (PI3-k) activity (20). In rats, increased FFA upregulates intracellular fatty acyl-CoA and diacylglycerol (DAG) concentrations, which lead to activation of protein kinase $\mathrm{C}$ (PKC)-theta. PKCtheta stimulates IRS-1-mediated PI3-k activity, which increases insulin-stimulated glucose transport activity (110). FFAs from dietary fat are also important signaling molecules binding to free fatty acid receptors (FFARs), which are
G protein-coupled receptors (GPCRs). Medium or longchain fatty acids (FAs) bind and activate GPR40/FFAR1 and GPR120/FFAR4, whereas short-chain FAs activate GPR43/FFAR2. FFARs are regarded as potential therapeutic targets to reduce FFA-mediated IR (44).

Obesity-associated FFAs induce inflammation via TLR4, the receptor for lipopolysaccharide (LPS) that plays a critical role in initiating intracellular nuclear factor-kappaB (NF$\kappa \mathrm{B})$-mediated signaling, leading to activation of innate immunity (112) and causing IR in AT (93) (Fig. 2). In HFDinduced obese mice, lipids accumulated in the liver and caused hepatic inflammation via $\mathrm{NF}-\kappa \mathrm{B}$ activation, resulting in IR (14). Studies in human subjects and in mice have revealed that dietary intake of saturated fat (palm oil) induces TLR4-mediated inflammation, NF- $\kappa \mathrm{B}$ activation, increases hepatic TG storage, energy metabolism, and induces IR (38).

TNF- $\alpha$ was identified as an early potential target in the treatment of IR in obesity (41). TNF- $\alpha$ released by AT may
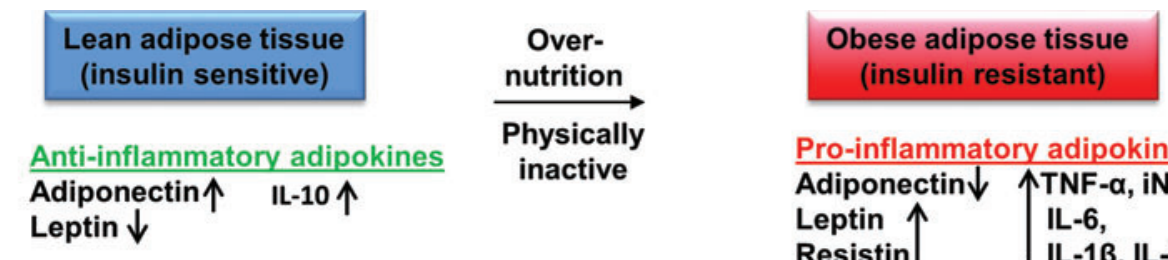

Pro-inflammatory adipokines \begin{tabular}{lll}
\hline $\begin{array}{l}\text { Adiponectin } \downarrow \\
\text { Leptin } \uparrow \\
\text { Resistin }\end{array}$ & $\begin{array}{l}\text { TNF- } \alpha, \text { iNOS } \\
\text { IL-6, }\end{array}$ & CCL2 \\
IL-1 $\beta$, IL-18 &
\end{tabular}

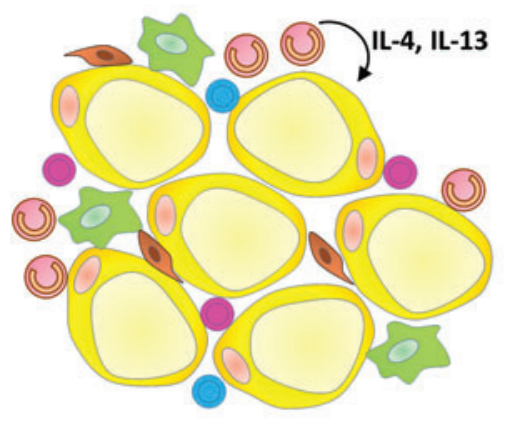

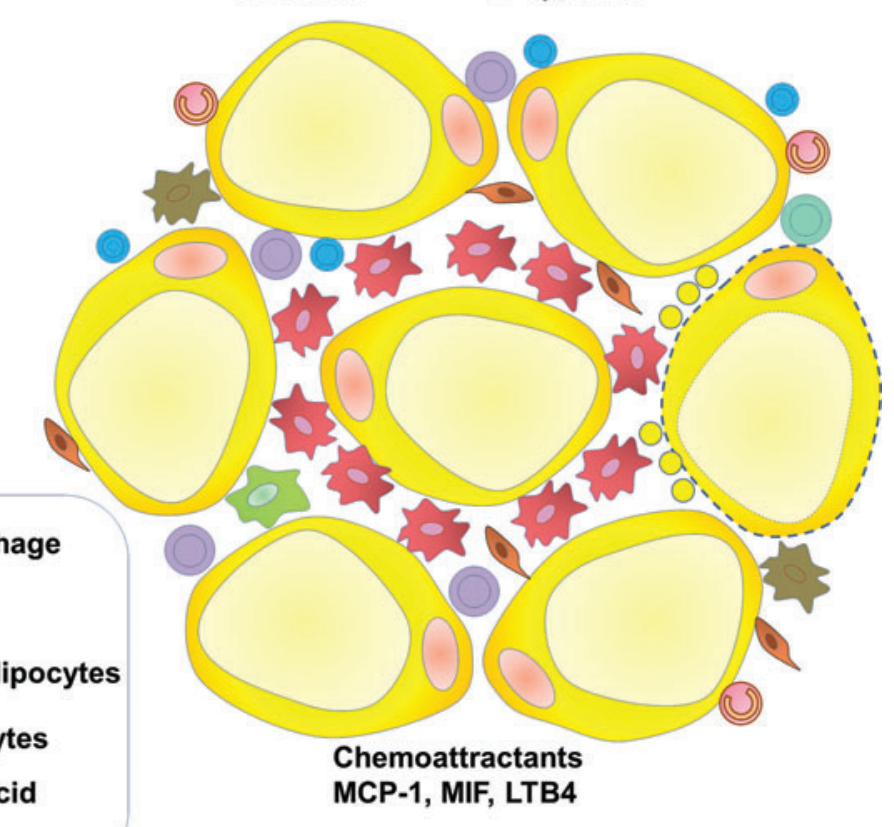

MCP-1, MIF, LTB4

FIG. 1. Macrophages and other immune cells distribution and function in lean and obese AT. In lean AT, M2 macrophages are distributed evenly throughout the tissue. Lean AT also contains CD4 ${ }^{+} \mathrm{T}$ cells, iNKT cells, and preadipocytes. Eosinophils secrete IL-4 and IL-13 that act on adipocytes and contribute to anti-inflammatory and insulinsensitive state. Adipokines such as adiponectin and IL-10 are increased, whereas leptin content is decreased. In obese AT, M1 macrophages form crown-like structures around the AT. M1 macrophages increase their number by both infiltration and local proliferation. Adipocyte hypertrophy causes the rupture of adipocytes and releases FFA. M1 macrophages secrete proinflammatory cytokines. The content of other immune cells also changes with eosinophils and regulatory $\mathrm{T}$ cells $\left(\mathrm{T}_{\text {reg }}\right)$ content, decreasing and dendritic cells, $\mathrm{CD}^{+}$and $\mathrm{CD}^{+} \mathrm{T}$ cell numbers increasing. The number of preadipocytes increases. Proinflammatory adipokines production such as TNF- $\alpha$, IL-6, IL-1 $\beta$, MCP-1, and MIF increases. AT, adipose tissue; FFA, free fatty acid; IL-6, interleukin-6; MCP-1, monocyte chemotactic protein-1; MIF, macrophage migration inhibitory factor; $\mathrm{TNF}-\alpha$, tumor necrosis factor alpha. To see this illustration in color, the reader is referred to the web version of this article at www.liebertpub.com/ars 

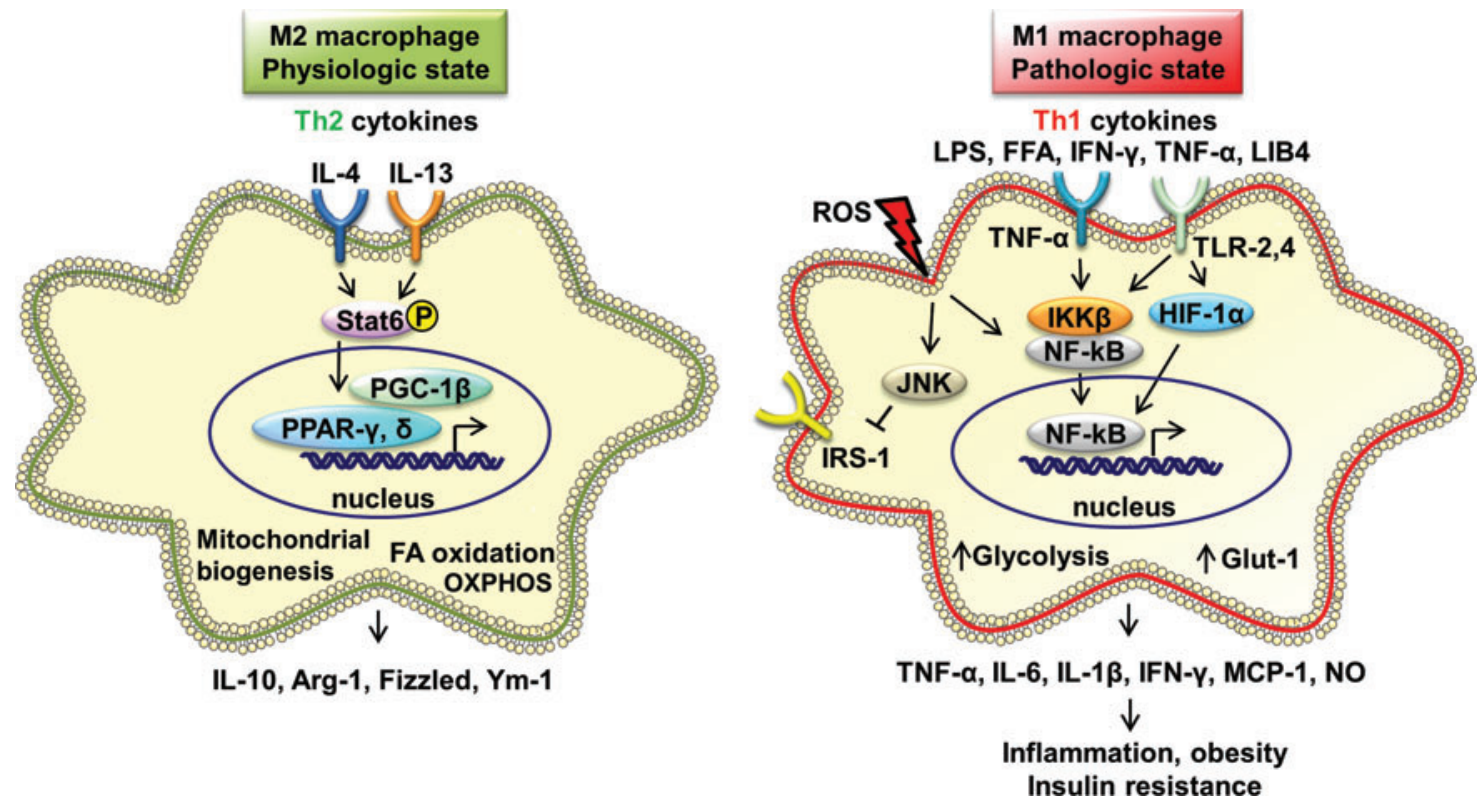

FIG. 2. Macrophage inflammatory pathways in physiological and pathological states of obesity and insulin resistance. M1 macrophages are activated by inflammatory inducers, TNF- $\alpha$, TLR-2, four ligands, IFN- $\gamma$, and ROS. M1 macrophages function via JNK and NF- $\kappa$ B pathways. Activated M1 macrophages release TNF- $\alpha$, IL- 6 , IL- $1 \beta$, IFN- $\gamma$, MCP1 , and NO, resulting in increased inflammation, obesity, and insulin resistance. M2 macrophages are activated by IL-4 and IL-13 that act via STAT6, PPAR- $\gamma$, PPAR- $\delta$, and PGC-1 $\beta$. M2 macrophages express IL-10, Arg-1, Fizzled, and Ym-1. M2 macrophages increase FA oxidation and OXPHOS. GLUT-1, glucose transporter-1; IFN- $\gamma$, interferon-gamma; IRS-1, insulin receptor substrate-1; JNK, c-Jun NH2-terminal kinase; LPS, lipopolysaccharide; NF- $\kappa \mathrm{B}$, nuclear factor-kappaB; NO, nitric oxide; OXPHOS, oxidative phosphorylation; PGC-1 $\beta$, peroxisome proliferator-activated receptor gamma coactivator 1-beta; PPAR- $\gamma$, peroxisome proliferator-activated receptor-gamma; ROS, reactive oxygen species; STAT6, signal transducer and activator of transcription 6; TLR, toll-like receptor. To see this illustration in color, the reader is referred to the web version of this article at www.liebertpub.com/ars

act through autocrine or paracrine functions, causing IR (3). Obesity-induced IR was improved by genetic or pharmacological inhibition of inhibitor of $\kappa \mathrm{B}$ kinase, which reduces $\mathrm{NF}-\kappa \mathrm{B}$ pathway activation, thus reducing $\mathrm{TNF}-\alpha$ production (57). TNF- $\alpha$-treated brown adipocytes induce proteintyrosine phosphatase 1 (PTP1B) and inhibition of PTP1B confers protection against cytokine-induced IR (21). The seminal observation of the link between TNF- $\alpha$ and metabolic disease has firmly focused attention on inflammation and the macrophage.

\section{Macrophage Phenotype in Obesity and Diabetes}

The activation state of macrophages present in a tissue has a profound effect on disease biology. Macrophages are immune cells with a highly plastic phenotype ranging from highly proinflammatory to an anti-inflammatory phenotype, these activation states are induced when the cells are exposed to specific stimuli (Fig. 3). Macrophage phenotype has been studied for many years using the expression of key genes, cytokines, and cell surface molecules as hallmarks of macrophages existing at the polar extremes of phenotype [reviewed in Ref. $(33,66)]$. The definition of macrophages as M1 or M2 is based on activation of cells in vitro with very defined stimuli, as defined by Mantovani et al. (64). M1 macrophages are generated after exposure of the cells to LPS, or FAs in the case of metabolic inflammation, which ligate TLRs on the cell surface, in the presence of interferon gamma $(\mathrm{IFN}-\gamma)(93)$. These cells have a broadly proinflammatory phenotype and upregulate both the cardinal proinflammatory cytokines TNF- $\alpha$, IL-1, and IL-6, and characteristic genes such as nitric oxide synthase 2 (NOS2). These classically activated macrophages show enhanced killing of intracellular pathogens and low levels of the anti-inflammatory cytokine

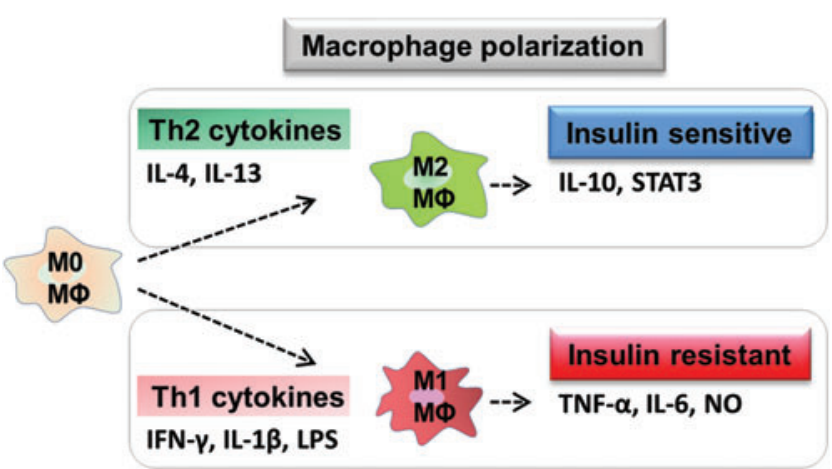

FIG. 3. Macrophage polarization and their effects on insulin regulation. Th2 cytokines such as IL-4 and IL-13 differentiate quiescent (M0) macrophages to M2 phenotype. M2 macrophages maintain the insulin-sensitive state by the release of IL-10 and STAT3. In contrast, Th1 cytokines in the presence of LPS (or other TLR ligands) differentiate macrophages to M1 phenotype. M1 macrophages promote insulin resistance by the release of TNF- $\alpha$, IL-6, and NO. STAT3, signal transducer and activator of transcription 3. To see this illustration in color, the reader is referred to the web version of this article at www.liebertpub.com/ars 
IL-10. When macrophages are exposed to IL-4 and/or IL-13, an alternatively activated M2 phenotype arises. These M2 macrophages secrete cytokines that oppose the M1-produced cytokines, including IL-10 and antagonists of the IL-1 pathway (IL-1ra and the decoy receptor IL-1RII), and express key marker genes such as increased arginase 1 (Arg-1), and Ym-1 [reviewed in Ref. (30)]. The cytokine IL-13 is known to induce the expression of M2 marker genes in both AT and liver (69). This M2 state of activation can be anti-inflammatory, but is also associated with allergy and immunity against pathogens. While in vivo such precise polarization of the cells is unlikely to happen, drawing parallels to the in vitro phenotype, defined by gene expression or cytokine/mediator production, allows some identification of macrophages seen in disease. Understanding the more varied stimuli that alter macrophage biology toward an M1 or M2-like phenotype and what mediates the positive or negative effect of these macrophages are key to our understanding of how macrophage biology plays a role in obesity and IR. For a comprehensive review of the paradigm of macrophage activation, see Mantovani et al. (64) and Martinez et al. (65).

Macrophages in lean AT are M2 phenotype, being F4/ $80^{+} \mathrm{CD} 206^{+} \mathrm{CD} 301^{+} \mathrm{CD} 11 \mathrm{c}^{-}$and sparsely distributed, whereas those in obese ATMs have an M1 phenotype, expressing $\mathrm{F} 4 / 80^{+} \mathrm{CD} 11 \mathrm{c}^{+}$and form crown-like structures (CLSs) surrounding the adipocytes $(22,31)$ (Fig. 1). M1 macrophages mediate the metabolic complications of obesity, both in AT and by infiltration into other metabolic organs such as skeletal muscle (90). In mice (fed HFD), obesity induces ATM polarization from M2 to M1 phenotype (58). M1 macrophages (Th1) induce IR by producing inflammatory mediators, such as TNF- $\alpha$, IL-6, and nitric oxide (NO) (58). M2 macrophages maintain insulin sensitivity by the anti-inflammatory actions of IL-10 and signal transducer and activator of transcription (STAT) 3 (58).

Recent studies in mouse models of obesity reveal some of the signaling pathways that mediate AT inflammation and the resulting macrophage polarization. JNKs are stress-activated protein kinases and are strongly associated with obesity and IR both in mice and humans. Saturated FAs, but not unsaturated FAs, activate JNK and inhibit insulin signaling via cSrc activation (39). Macrophage-specific deletion of JNK in mice protects from obesity-induced IR (fed HFD) by reducing infiltration of macrophages into pancreatic islets and ATM M1 polarization (35). Micro RNA-155 in adiposederived microvesicles induced M1 macrophage polarization and caused chronic inflammation and local IR (111), indicating a further mechanism of obesity-induced proinflammatory signaling.

ATMs originate from bone marrow monocytes and infiltrate the tissue via blood circulation. MCP-1 stimulates the proliferation of ATM locally in VAT in genetically obese mice (ob/ob) (1). MCP-1 binds to chemokine (C-C motif) receptor 2 (CCR2) and causes macrophage migration (89). In obesity, the cytokine MIF is enhanced and linked to obesityassociated inflammation and IR, indicating that it may be a primary cytokine promoting ATM recruitment during obesity (24). MIF also promotes secretion of TNF- $\alpha$, IL-6, and IL-1 $\beta$, and inhibits IL-10 production, increasing inflammation (15). Obese (HFD-fed) MIF deficient mice were protected from weight gain and IR by attenuating M1 ATM infiltration, TNF- $\alpha$, and increased expression of IL-10 (23).
The STAT6 and nuclear receptors peroxisome proliferatoractivated receptor (PPAR)- $\gamma$ and PPAR- $\delta$ also play an important role in M2 macrophage polarization $(11,78)$. Macrophage-specific PPAR- $\delta$ deletion diminishes M2 macrophage activation, resulting in impaired glucose tolerance and systemic IR (77). PPAR- $\delta$ causes M2 macrophage polarization in both WAT and liver (69). IL-33 is recently identified as a member of IL-1 gene family and is expressed in human AT (adipocytes and preadipocytes) and also expressed in response to TNF- $\alpha$ (105). IL-33 induces the production of Th2 cytokines (IL-5, IL-13, and IL-10) and accumulation and polarization of $\mathrm{M} 2$ macrophages (CD206 ${ }^{+}$) in WAT and is protective in obese mice by modulating AT inflammation (69).

Macrophages deficient in fatty acid synthase protect HFDfed mice from IR, macrophage recruitment in AT, and chronic inflammation (102). NKT cells interact with CD1d, expressing antigen-presenting cells such as adipocytes, macrophages, dendritic cells, and B cells. In lipid excess environments, NKT cells interact with the endogenous lipid ligand CD1d on adipocytes and produce IFN- $\gamma$. This induces AT inflammation by increasing the expression of CD1d, MCP-1, and chemokine (C-X-C motif) ligand 16 (CXCL16) and decreasing expression of adiponectin (92). CD1d-deficient HFD-fed mice have decreased ATM recruitment, resulting in reduced obesity and improved insulin sensitivity (91).

Other immune cells such as neutrophils and T cells (subpopulations, CD4, CD8, and natural killer cells) are also increased in obese AT (Fig. 1). Neutrophils are reported to infiltrate the AT in 3 days after mice begin to consume a HFD (96). In lean AT, eosinophils are anti-inflammatory by secreting IL-4 and IL-13, but in obese AT, eosinophil content decreases. In obesity, regulatory $T$ cells $\left(T_{\text {reg }}\right)$ decline and increased $\mathrm{CD}^{+}$and $\mathrm{CD}^{+} \mathrm{T}$ cells secrete proinflammatory cytokines. HFD feeding in mice causes infiltration of $\mathrm{CD}^{+} \mathrm{T}$ cells in WAT, which, in turn, activates the accumulation of $\mathrm{F} 4 / 80^{+} \mathrm{CD} 11 \mathrm{~b}^{+}$macrophages in WAT (73).

\section{The Role of Reactive Oxygen Species and Oxidative Stress, Macrophage Polarization}

Reactive oxygen species (ROS) (oxygen-free radicals) are essential signaling molecules in various biological processes such as gene expression, protein translation, post-translational modification, and protein interactions. ROS such as superoxide anion $\left(\mathrm{O}_{2}^{-}\right)$, hydrogen peroxide $\left(\mathrm{H}_{2} \mathrm{O}_{2}\right)$, and hydroxyl radical $\left({ }^{\bullet} \mathrm{OH}\right)$ are generated by the mitochondrial oxidative metabolism and degradation of FAs in peroxisomes, cytochrome P450 enzymes, Kupffer cells, and neutrophils [reviewed in Ref. (67)]. The mitochondrial respiratory system is a major contributor of ROS production in physiological conditions (72). Cells maintain the balance between oxidant and antioxidant defense molecules in addition to regulating their intracellular ROS levels. Over production of ROS may cause pathophysiological events such as oxidation of proteins and lipids and DNA damage, as a consequence cells repair damage, or die by necrosis or apoptosis (12).

Adipocytes synthesize ROS in the presence of glucose and palmitate. Excess amounts of glucose and palmitate increase the expression of ROS via nicotinamide adenine dinucleotide phosphate (NADPH) oxidase 4 (Nox4) in adipocytes (34). Treatment of macrophages with LPS and IFN- $\gamma$ synthesizes 
NO production by increasing the production of inducible NOS (iNOS) [reviewed in Ref. (54)]. NO is known to inhibit mitochondrial respiration. HFD-fed iNOS-deficient mice are protected from infiltration of proinflammatory macrophages and AT fibrosis. In vitro macrophage-derived NO reduces the expression of mitochondrial biogenesis factors and increases hypoxia-inducible factor-1 (HIF- $1 \alpha$ ), DNA damage, and activation of p53 in preadipocytes (46). Macrophage-released NO activates p53 that results in suppression of PPAR- $\gamma$ coactivator $1 \alpha(\mathrm{PGC}-1 \alpha)$ and mitochondrial dysfunction in preadipocytes (46). Macrophages can additionally generate ROS via the activation of Nox2. ROS is produced in the presence of excess FAs; adipocytes increase oxidative stress via NADPH oxidase activation, which leads to dysregulated production of adiponectin, plasminogen activator inhibitor (PAI)-1, IL-6, and MCP-1 (28). Glucose-induced increases in ROS production in macrophages cause proinflammatory polarization and IR in mice [reviewed in Ref. (40)]. In obese mice, inhibition of NADPH oxidase leads to reduced ROS production in AT, diminished the dysregulation of adipokines, and improved diabetes and hyperlipidemia (28). HFD-fed and insulin-resistant obese mice showed increased production of ROS in adipocytes. Adipocytes in HFD-fed and obese insulin-resistant mice express elevated ROS production by the activation of PKC- $\delta$ and NADPH oxidase (95).

\section{Macrophage Polarization and Cellular Metabolism}

Alongside their well-characterized gene and protein expression signatures, M1 and M2 macrophages have markedly different metabolic processes. When in a resting state, macrophages meet their energy requirements using oxidative phosphorylation (OXPHOS). Glucose molecules enter glycolysis to produce pyruvate, with a single glucose molecule yielding two molecules of pyruvate. Under resting normoxic conditions, pyruvate enters the mitochondria where it is consumed by the tricarboxylic acid (TCA) cycle with ATP generated by OXPHOS. In contrast, macrophages activated under M1 conditions, such as after LPS stimulation, undergo dramatic metabolic changes. Uptake of glucose increases, and aerobic glycolysis becomes the principal metabolic pathway [reviewed in Ref. $(54,82)]$. The increased glucose uptake increases flow through the glycolytic pathway, with increased pyruvate kinase muscle isozyme M2 (PKM2) expression, facilitating production of pyruvate to support lactate production and supply the TCA cycle (81). This altered metabolism, called the Warburg effect, causes buildup of ATP. The glycolytic intermediates support nucleotide and amino acid synthesis as well providing substrates for the pentose phosphate pathway to produce NADPH. The reduction in mitochondrial electron transport chain activity results in mitochondrial ROS production that, alongside the increased availability of NADPH for NADPH oxidase activity, results in a cell with a highly proinflammatory redox status (104). The Warburg effect is primarily associated with cells undergoing rapid proliferation, but this is not the case in M1 macrophages; instead, the increased glucose consumption is associated with rapid cytokine production and enhanced antimicrobial activity through ROS generation (104). Although a comparatively inefficient means to produce ATP, glycolysis is sufficient for macrophage function, providing glucose availability and uptake are not limiting. A combined metabolomics and transcriptomics approach has revealed that as well as a switch to glycolysis, M1 macrophages have a "broken" TCA cycle (48) (Fig. 4). The flow of metabolites around the TCA cycle is interrupted at the level of isocitrate dehydrogenase, leading to a reduction in the production of alpha-ketogluarate from citrate. This causes citrate to accumulate in M1-activated cells, which can then support FA synthesis. The "broken" TCA cycle also accumulates succinate in M1 macrophages, rather than proceeding to form fumarate and malate. The excess succinate production can lead to induction of IL- $1 \beta$, adding to the proinflammatory nature of the M1 cells, and causes HIF-1 $\alpha$ induction (81).
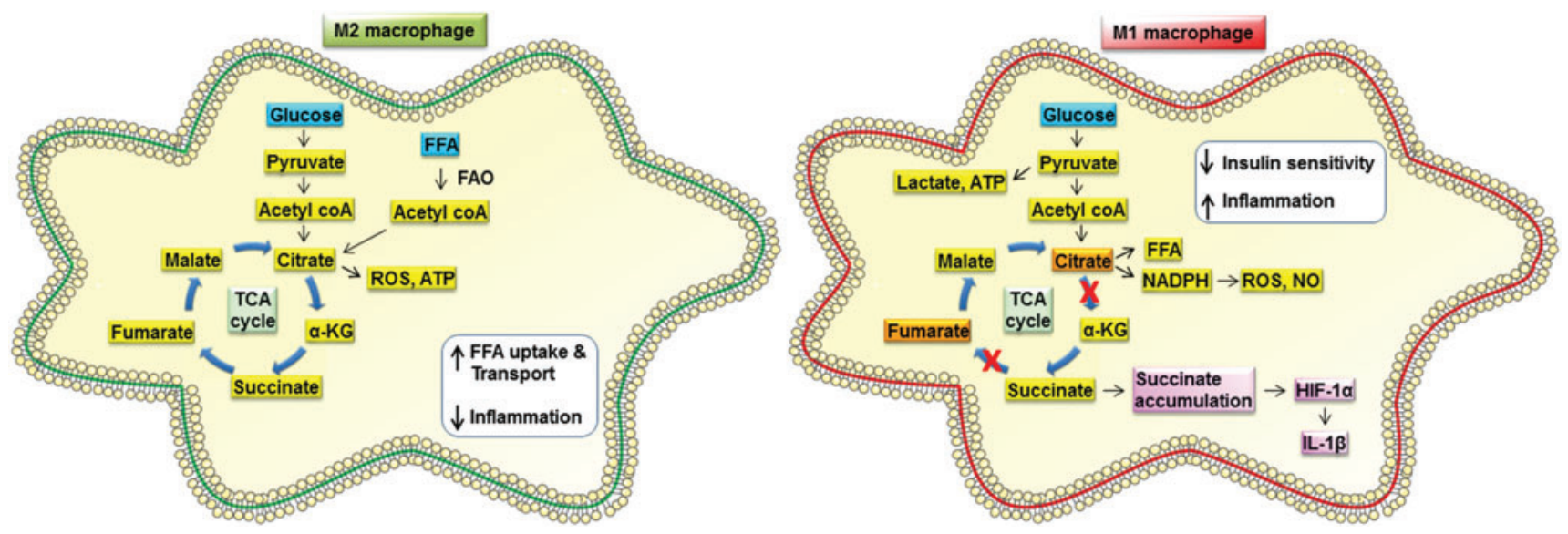

FIG. 4. Immunometabolic differences between M2 and M1 macrophages. Both M1 and M2 macrophages can produce energy by glucose metabolism. M2 macrophages use OXPHOS and the TCA cycle, similarly to quiescent macrophages, but additionally demonstrate increased FFA uptake and oxidation (FAO) to supplement the TCA cycle and their energy needs. M1 macrophages increase glucose uptake and produce energy via oxidative glycolysis, resulting in lactate production. In addition, they exhibit a broken TCA cycle leading to the accumulation of both citrate and succinate. Succinate accumulation leads proinflammatory cytokine IL- $1 \beta$ release via HIF- $1 \alpha . \alpha-\mathrm{KG}$, alpha-ketoglutarate; FAO, fatty acid oxidation; HIF- $1 \alpha$, hypoxia-inducible factor- $1 \alpha$; NADPH, nicotinamide adenine dinucleotide phosphate; TCA, tricarboxylic acid. To see this illustration in color, the reader is referred to the web version of this article at www.liebertpub.com/ars 
In contrast to M1 macrophages that synthesize FAs downstream of citrate accumulation, M2 macrophages metabolize FAs in addition to glucose to supply the TCA cycle (Fig. 4). The TCA cycle is intact in M2 macrophages and is coupled to OXPHOS (48). When differentiated using IL-4, M2 macrophages show a significant increase in FA uptake and oxidation (FAO or B oxidation) to fuel mitochondrial OXPHOS. Treatment of macrophages with either compounds to block FAO (etomoxir) or to inhibit OXPHOS (FCCP and oliogmycin) both decrease arginase activity, a defining feature of an M2 macrophage along with surface expression of CD301 and CD206 (42, 98). The induction of gene expression pathways supporting FAO and mitochondrial biogenesis by PPAR- $\gamma$ and PPAR $-\gamma$ coactivator 1 -beta (PGC- $1 \beta$ ) in response to IL-4 underpins the changes in metabolic state that occur with M2 differentiation (98). M2 macrophages use cell-intrinsic lysosomal lipolysis as a source for the FAs required by this metabolic program (42). Inhibiting lipolysis using tetrahydrolipistatin (orlistat) in M2 macrophages reduces OXPHOS, but has no effect on metabolism in M1 macrophages. Orlistat treatment reduces hallmark M2 cell surface marker expression, confirming the requirement of FAO for M2 differentiation (42). Uptake of FAs via the scavenger receptor (CD36) before lipolysis by lysosomal acid lipase appears to be an important mechanism providing substrate for FAO in M2 macrophages (42). Although providing convincing evidence that FAO is required for the M2 phenotype, nonpharmacological approaches have indicated that the link may be less straightforward. Conditional macrophage-specific knockout of carnitine palmitoyltransferase (CPT) 2, a mitochondrial protein essential for FAO, reveals that bone marrowderived macrophages (BMDMs) can still express M2 markers in the absence of FAO (75). Whether FAO is an absolute requirement for $\mathrm{M} 2$ macrophage function or not, the association with this anti-inflammatory cell type is clear.

The strong link between macrophage polarization and cellular metabolism raises the possibility that modulation of macrophage metabolic state may be a therapeutic target. The glycolytic switch in macrophage metabolism as they undergo classical M1 activation is based on glycolysis being fundamental to the inflammatory capability of M1 macrophages, rather than a secondary result of M1 activation. Experiments to modulate expression of key elements of the metabolic pathways in macrophages have been undertaken in recent years to assess the extent to which macrophage inflammatory status can be modulated by targeting cellular metabolism. The glucose transporter (GLUT) 1 is upregulated in inflamed obese AT, colocalizing with macrophages in CLSs (27). GLUT1 overexpression in the RAW macrophage cell line is associated with increased glucose uptake, glycolytic rate, and lactate production. These cells exhibit enhanced gene expression and secretion of a range of inflammatory mediators, such as IL-1, IL-6, and $\mathrm{TNF}-\alpha$ and, in the presence of LPS, further enhanced expression of the inflammatory mediator PAI-1 (27). These observations imply that altering metabolic status can control inflammation, in the absence of other inflammatory signals; however, a similar study by Nishizawa et al. (74) has reported conflicting findings. Overexpression of GLUT1 in the J774 cell line or in BMDMs produces the expected increase in glycolysis, but did not alter IL-6 expression (74). Similarly, in vivo experiments with retroviral GLUT1 overexpression in monocytes (driven by the CD68 promoter) after bone marrow chimerization did not demonstrate any altered cytokine secretion by peritoneal macrophages in the thiogylcollate model of peritonitis, despite increased glucose uptake measured using D-glucose positron emission tomography (18-FDG PET) analysis (74).

Macrophage phenotype can also be altered through altering FA uptake. Fatty acid transport protein 1 (FATP1) is reduced in M1 macrophages, but expression is maintained in M2 macrophages (50). Knockout of FATP1 in macrophages resulted in elevated energy production by OXPHOS both in M2 macrophages and resting or M1 activated cells. These changes were associated with a priming of macrophages toward the proinflammatory M1 state with a greater upregulation of NOS2 in M1-activated cells and a blunted expression of arginase 1 in M2-activated cells (50). In vivo experiments using bone marrow chimerization showed that loss of FATP1 in leukocytes alone increased weight gain, adiposity, and glucose intolerance under HFD conditions. AT in these mice showed signs of increased proinflammatory M1 macrophage activity with an increase in CLSs and proinflammatory gene expression (50). The ability of a single gene controlling FA metabolism in leukocytes to cause measureable changes in obesity and insulin sensitivity at the whole animal level underlines the potential power of altering immunometabolism. The converse experiment of overexpressing FATP1 in a macrophage cell line (RAW264.7) decreased GLUT1 expression using the M1 stimulus LPS and decreased glycolytic rate in both resting and stimulated cells. This change was accompanied by a decreased proinflammatory gene expression (50). Further evidence of an association of metabolic reprogramming with metabolic disease shows that obese and T2D individuals have reduced levels of FAO rates. The expression of CPT1A is higher in human ATM than mature adipocytes (63). CPT1 overexpression increases FAO levels in ATM. CPT1 expressing macrophages restored palmitate-induced increase in TG, inflammation, ER, and oxidative stress. Increase of FAO in lipid-treated adipocytes and macrophages reduced TG content, inflammatory cytokine levels, reduced ER stress, and ROS damage to macrophages, and improved insulin sensitivity in adipocytes (63).

These examples of the ability of the cell membrane nutrient transporters such as GLUT1 and FATP1 to alter macrophage phenotype indicate that local nutrient availability may also impact macrophage phenotype through the modulation of intracellular metabolism through excess or limited substrate availability. This seems likely to be of particular relevance in metabolic conditions typified by altered systemic glucose control and thus availability. As future studies investigate the immunometabolic state of macrophages in both lean and obese AT, the contribution of these metabolic alterations as potentially both causative and therapeutic will become clearer.

\section{Macrophage Metabolic Reprogramming}

In addition to the examples of GLUT1 and FATP directly demonstrating modulation of macrophage metabolism, the identification of signaling pathways within macrophages that program the macrophage metabolic phenotype is a current research focus across multiple fields. We highlight here some of the recent findings that relate to relevant pathways associated with metabolic disease. Table 1 summarizes current targets that show promising relevance for future investigation in ATMs, which are covered in this review. 
Table 1. Targets for Macrophage Metabolic Reprogramming in Adipose Tissue Macrophages

\begin{tabular}{|c|c|c|c|c|c|}
\hline $\begin{array}{l}\text { Targets for } \\
\text { macrophage } \\
\text { metabolic } \\
\text { reprogramming }\end{array}$ & M1 macrophages & M2 macrophages & $\begin{array}{l}\text { In vivo effects } \\
\text { relating to monocytel } \\
\text { macrophage function }\end{array}$ & $\begin{array}{l}\text { Link with } \\
\text { intracellular } \\
\text { macrophage } \\
\text { metabolism }\end{array}$ & Ref. \\
\hline GLUT1 & $\begin{array}{l}\text { Overexpression in } \\
\text { RAW cells } \\
\text { increases M1 } \\
\text { cytokines: IL-1, } \\
\text { IL-6, and TNF- } \alpha \text {. } \\
\text { An increase in IL-6 } \\
\text { is not seen in J774 } \\
\text { cells. }\end{array}$ & - & $\begin{array}{l}\text { Endogenous expression } \\
\text { is increased in } \\
\text { inflamed obese } \\
\text { adipose tissue. } \\
\text { Overexpression in } \\
\text { monocytes increases } \\
\text { glucose uptake but } \\
\text { did not alter cytokine } \\
\text { production. }\end{array}$ & $\begin{array}{l}\text { Overexpression } \\
\text { increases glucose } \\
\text { uptake, glycolytic } \\
\text { rate, and lactate } \\
\text { production. }\end{array}$ & (74) \\
\hline \multirow[t]{2}{*}{ FATP } & $\begin{array}{l}\text { Endogenous } \\
\text { expression reduced } \\
\text { on differentiation. }\end{array}$ & $\begin{array}{l}\text { Endogenous } \\
\text { expression } \\
\text { maintained on } \\
\text { differentiation. }\end{array}$ & $\begin{array}{l}\text { Mice lacking FATP in } \\
\text { leukocytes show } \\
\text { increased weight } \\
\text { gain, adiposity, and } \\
\text { glucose tolerance on } \\
\text { a high-fat diet. }\end{array}$ & $\begin{array}{l}\text { Knockout of FATP } \\
\text { increases energy } \\
\text { production by } \\
\text { OXPHOS in M1 } \\
\text { and M2 } \\
\text { macrophages. }\end{array}$ & $(50)$ \\
\hline & $\begin{array}{l}\text { FATP }{ }^{-/-} \mathrm{M} 1 \\
\text { macrophages show } \\
\text { M1 priming, with } \\
\text { increased iNOS } \\
\text { expression. } \\
\text { FATP overexpression } \\
\text { reduces GLUT1 } \\
\text { expression. }\end{array}$ & $\begin{array}{l}\text { FATP }{ }^{-/-} \mathrm{M} 2 \\
\text { macrophages } \\
\text { show blunted } \\
\text { arginase } \\
\text { expression }\end{array}$ & & $\begin{array}{l}\text { FATP overexpression } \\
\text { decreases } \\
\text { glycolytic rate in } \\
\text { resting and M1 } \\
\text { macrophages }\end{array}$ & \\
\hline \multirow[t]{2}{*}{ Notch } & $\begin{array}{l}\text { Notch1-RBP-J } \\
\text { signaling promotes } \\
\text { M1 polarization. }\end{array}$ & $\begin{array}{l}\text { Notch-RBP-J } \\
\text { signaling inhibits } \\
\text { M2 macrophage } \\
\text { polarization by } \\
\text { downregulating } \\
\text { JMJD3. }\end{array}$ & $\begin{array}{l}\text { Notch inhibitor DAPT } \\
\text { attenuated glycolysis, } \\
\text { reducing glucose } \\
\text { uptake and lactate } \\
\text { formation in hepatic } \\
\text { macrophages in }\end{array}$ & $\begin{array}{l}\text { Notch induces } \\
\text { pyruvate } \\
\text { dehydrogenase } \\
\text { phosphatase that } \\
\text { supports the TCA } \\
\text { cycle. }\end{array}$ & (101) \\
\hline & $\begin{array}{l}\text { Notch } 1^{-1-} \text { hepatic } \\
\text { macrophages show } \\
\text { reduced M1 gene } \\
\text { expression after } \\
\text { LPS stimulation } \\
\text { in vitro. }\end{array}$ & & $\begin{array}{l}\text { response to alcoholic } \\
\text { steatohepatitis. }\end{array}$ & $\begin{array}{l}\text { Notch regulates } \\
\text { transcription of } \\
\text { respiratory chain } \\
\text { proteins. }\end{array}$ & $\begin{array}{l}(70) \\
(108)\end{array}$ \\
\hline IL-10 & $\begin{array}{l}\text { IL-10 is induced by } \\
\text { M1 macrophages } \\
\text { and acts as a } \\
\text { cell-autonomous } \\
\text { regulator of } \\
\text { glycolysis. }\end{array}$ & $\begin{array}{l}\text { IL-10 is highly } \\
\text { upregulated by } \\
\text { M2 macrophages. }\end{array}$ & $\begin{array}{l}I L-10^{-/} \text {macrophages } \\
\text { from an } \\
\text { inflammatory colitis } \\
\text { model show a } \\
\text { buildup of damaged } \\
\text { mitochondria and } \\
\text { increased } \\
\text { inflammation } \\
\text { because of } \\
\text { inflammasome } \\
\text { activation. }\end{array}$ & $\begin{array}{l}I L-10^{-/-} \mathrm{M} 1 \\
\text { macrophages show } \\
\text { increased } \\
\text { glycolytic activity } \\
\text { and reduced } \\
\text { OXPHOS. } \\
\text { IL-10 reduces GLUT1 } \\
\text { expression on the } \\
\text { cell surface. }\end{array}$ & $(45)$ \\
\hline CARKL & $\begin{array}{l}\text { LPS downregulates } \\
\text { endogenous } \\
\text { CARKL } \\
\text { expression. } \\
\text { CARKL } \\
\text { overexpression } \\
\text { reduces IL-6 and } \\
\text { TNF- } \alpha \text { in response } \\
\text { to LPS. } \\
\text { CARKL } \\
\text { macrophages } \\
\text { expression of M1 } \\
\text { cytokines without } \\
\text { further stimulation. }\end{array}$ & $\begin{array}{l}\text { M2 macrophages } \\
\text { upregulate } \\
\text { CARKL }\end{array}$ & - & $\begin{array}{l}\text { CARKL is an orphan } \\
\text { receptor in the } \\
\text { pentose phosphate } \\
\text { pathway. } \\
C A R K L^{-I-} \\
\text { macrophages show } \\
\text { enhanced } \\
\text { glycolysis, without } \\
\text { additional } \\
\text { stimulation. }\end{array}$ & (37) \\
\hline
\end{tabular}


TABle 1. (CONTINUED)

\begin{tabular}{|c|c|c|c|c|c|}
\hline $\begin{array}{l}\text { Targets for } \\
\text { macrophage } \\
\text { metabolic } \\
\text { reprogramming }\end{array}$ & M1 macrophages & M2 macrophages & $\begin{array}{l}\text { In vivo effects } \\
\text { relating to monocytel } \\
\text { macrophage function }\end{array}$ & $\begin{array}{l}\text { Link with } \\
\text { intracellular } \\
\text { macrophage } \\
\text { metabolism }\end{array}$ & Ref \\
\hline IL-4 & $\begin{array}{l}\text { IL-4 treatment is not } \\
\text { sufficient to } \\
\text { repolarize M1 } \\
\text { macrophages. } \\
\text { Nitric oxide } \\
\text { produced by M1 } \\
\text { macrophages } \\
\text { prevents } \\
\text { repolarization. }\end{array}$ & $\begin{array}{l}\text { IL-4 promotes M2 } \\
\text { polarization. } \\
\text { Repolarization to } \\
\text { M2 requires } \\
\text { mitochondrial } \\
\text { function. }\end{array}$ & - & $\begin{array}{l}\text { Inhibition of iNOS } \\
\text { allows IL-4 to } \\
\text { repolarize M1 cells, } \\
\text { reducing glycolysis } \\
\text { and promoting } \\
\text { OXPHOS. }\end{array}$ & (97) \\
\hline mTOR pathway & $\begin{array}{l}\text { Inhibition of both } \\
\text { mTORC1 and } \\
\text { mTORC2 promotes } \\
\text { M1 polarization. }\end{array}$ & $\begin{array}{l}T s c^{-/-} \text {macrophages } \\
\text { show defective } \\
\text { M2 polarization in } \\
\text { response to IL-4. }\end{array}$ & $\begin{array}{l}\text { Macrophage-specific } \\
\text { mTORC1 }{ }^{-I-} \text { mice } \\
\text { show less } \\
\text { inflammation after } \\
\text { high-fat feeding. }\end{array}$ & $\begin{array}{l}T s c^{-/-} \text {macrophages } \\
\text { show no increase in } \\
\text { FAO in response to } \\
\text { IL-4. }\end{array}$ & (49) \\
\hline $\begin{array}{l}\text { mTORC1/2 are } \\
\text { multisubunit } \\
\text { complexes } \\
\text { within the } \\
\text { pathway }\end{array}$ & $\begin{array}{l}\text { Deletion of Tsc1 } \\
\text { enhances mTORC1 } \\
\text { activity. Tscl } \\
\text { macrophages show } \\
\text { increased } \\
\text { proinflammatory } \\
\text { cytokine } \\
\text { production and } \\
\text { reduced IL-10 } \\
\text { production. }\end{array}$ & & $\begin{array}{l}\text { Global mTORC1 } \\
\text { inhibition with } \\
\text { rapamycin } \\
\text { increases the } \\
\text { number of M1 mac- } \\
\text { rophages after high- } \\
\text { fat feeding. }\end{array}$ & $\begin{array}{l}\text { mTORC2-deficient } \\
\text { macrophages show } \\
\text { defective OXPHOS } \\
\text { utilization after } \\
\text { IL-4 stimulation. }\end{array}$ & $\begin{array}{l}(13) \\
(83)\end{array}$ \\
\hline
\end{tabular}

CARKL, carbohydrate kinase-like protein; FAO, fatty acid oxidation; FATP, fatty acid transport protein; GLUT-1, glucose transporter-1; IL-6, interleukin-6; iNOS, inducible NOS; JMJD3, Jumonji domain-containing 3; LPS, lipopolysaccharide; mTORC, mechanistic target of rapamycin complex; OXPHOS, oxidative phosphorylation; RBP-J, recombining binding protein suppressor of hairless; TCA, tricarboxylic acid; TNF- $\alpha$, tumor necrosis factor alpha.

\section{Notch}

The Notch signaling system has relevance to metabolic disease at multiple levels. The Notch signaling pathway consists of Notch receptors (Notch 1-4) and Notch ligands (delta-like [D11]: D111, D113, and Dll4, and Jagged: Jag1 and Jag2), which are important for cell-cell communication, development, and required for cellular homeostasis [reviewed in Refs. $(2,55)]$. Binding of Notch receptors to their ligands leads to proteolytic cleavage of Notch, resulting in the release of Notch intracellular domain (NICD) (Fig. 5a). The NICD binds to the recombining binding protein suppressor of hairless (RBP-J) in the nucleus [reviewed in Ref. (55)]. Notch-1 regulates the expression of Dll4 (Notch ligand) via RBP-J. The GPCR-kinase interacting protein-1 (GIT1) was proven to inhibit the Notch-1-Dll4 signaling (62). The Notch1-RBP-j signaling promotes M1 macrophage polarization via the synthesis of interferon-regulatory factor 8 and via NF- $\kappa \mathrm{B}$ signaling and inhibits M2 macrophage polarization by downregulating Jumonji domain-containing 3 (70, 107) (Fig. 5b). In adipocytes, Notch signaling promotes production of proinflammatory cytokines (TNF- $\alpha$, IL-1 $\beta$ ) via $\mathrm{NF}-\kappa \mathrm{B}$ signaling, resulting in the infiltration of macrophages, low-grade systemic inflammation, and IR. In obesity, infiltrated macrophages activate Dll4 via $\mathrm{NF}-\kappa \mathrm{B}$ signaling (8). Notch-1 is necessary for the differentiation of 3T3-L1 fibroblasts into adipocytes by decreasing the expression of transcription factors PPAR- $\gamma$ and PPAR- $\delta$ (29). Notch re- ceptors and Notch targets are expressed highly in visceral epididymal WAT than in subcutaneous inguinal WAT. Inhibition of Notch signaling in obese mice (fed HFD) promotes browning of WAT, elevated expression of UCP1 in WAT, and ameliorates and transcription factor forkhead box protein O1 (FoxO1)-driven hepatic IR (9, 80). Moreover, inactivation of Notch signaling ameliorates obesity in obese mice (fed HFD) and reduces blood glucose levels (9). In hepatocytes, abnormal Notch signaling (gluconeogenesis and lipogenesis) leads to hyperglycemia and fatty liver disease. Notch regulates hepatic glucose production via the synergy of NICD and FoxO1 [reviewed in Ref. (8)].

In addition to these well-established roles for Notch proteins, this pathway has also been shown to have a direct effect on macrophage mitochondrial metabolism in a model of alcoholic steatohepatitis (ASH). Macrophages isolated from the liver of mice subjected to this model demonstrate the expression of M1 phenotypic markers such as iNOS, TNF- $\alpha$, and IL-1 $\beta$ (108). Notch $1^{-/-}$hepatic macrophages also showed an attenuation of M1 gene expression when challenged with LPS in vitro. Inhibition of Notch using the $\gamma$-secretase inhibitor DAPT (N-[N-(3,5-difluorophenacetyl)-L-alanyl]-Sphenylglycine $t$-butyl ester) attenuated the increase in glucose uptake and lactate production, hallmarks of increased glycolysis, in primary hepatic macrophages from ASH mice (108). Notch was shown to mediate effects on metabolism by induction of pyruvate dehydrogenase phosphatase, which has a key function in passing glucose to the TCA cycle. The 

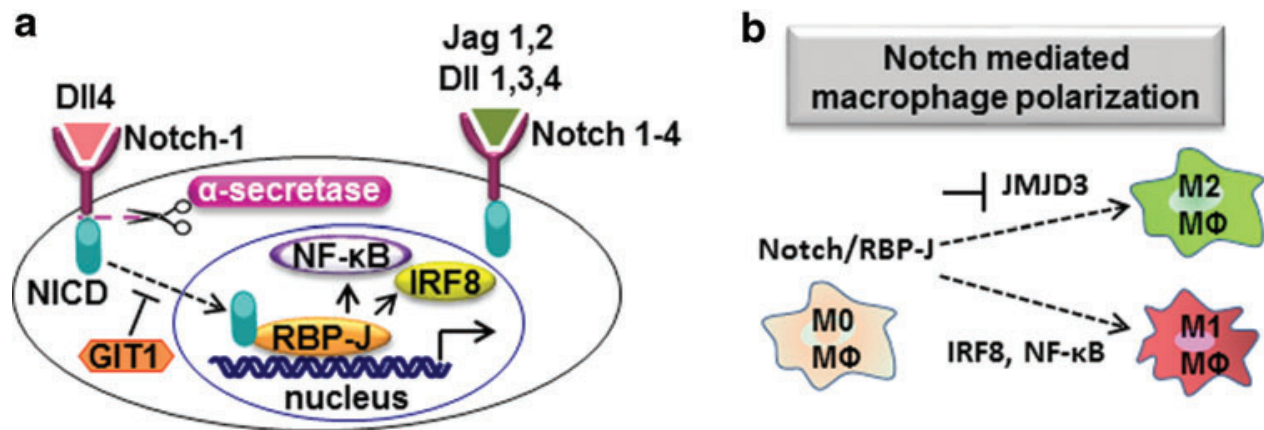

FIG. 5. (a) The role of Notch signaling in macrophage polarization. Notch signaling promotes M1 macrophage polarization by synthesizing IRF8 and NF- $\kappa \mathrm{B}$ and inhibits M2 macrophage polarization by downregulating JMJD3. (b) The Notch signaling pathway. The Notch ligands (Dll1, Dll3, and Dll4 and Jag1 and Jag2) bind to the Notch receptors (Notch 14). Upon ligand binding to the Notch receptor, proteolytic cleavage takes place (via $\alpha$-secretase) in Notch receptor, resulting in the release of NICD. The NICD translocates to the nucleus and binds to RBP-J, resulting in the release of IRF8 and NF$\kappa \mathrm{B}$. The GIT1 inhibits the Notch1-D114 mediated signaling. Dll, delta like; GIT1, G protein-coupled receptor-kinase interacting protein-1; IRF8, interferon regulatory factor 8; Jag, Jagged; JMJD3, Jumonji domain-containing 3; NF- $\kappa$ B, nuclear factor kappa light chain enhancer of activated B cells; NICD, Notch intracellular domain; RBP-J, recombining binding protein suppressor of hairless. To see this illustration in color, the reader is referred to the web version of this article at www.liebertpub.com/ars

ability of Notch to control macrophage metabolism was shown to be pleiotropic with additional transcription regulation of genes encoding respiratory chain proteins, encoded both by nuclear and mitochondrial DNA (108). Addressing the role of Notch in the biology of ATM in healthy and inflamed ATs has the potential to reveal a key element role for Notch in these macrophages as well.

\section{IL-10}

We have discussed the two archetypal extremes of macrophage polarization in this review-M1 and M2 macrophages. A key cytokine produced by M2 macrophages is IL-10, which has an anti-inflammatory activity. A recent study has shown that IL-10 has the ability to directly affect macrophage metabolic reprogramming. Activation of BMDMs from $I L-10^{-1-}$ and control mice demonstrated that in response to LPS, IL-10-deficient cells demonstrated an exaggerated switch to glycolytic activity and reduction in OXPHOS (45). These effects could be reversed by rescue of the IL-10deficient cultures with exogenous IL-10. IL-10 was shown to oppose metabolic switch by reducing macrophage glucose uptake as a result of opposing the cell surface upregulation of GLUT1 (45). When subjected to an inflammatory model, in this case a colitis model, macrophages $I L-10^{-/-}$mice showed a buildup damaged mitochondria, which can contribute to exaggerated inflammation by activation of the inflammasome and production of IL-1 $\beta$ (45). This ability of IL-10 to control mitophagy indicates another facet of metabolic regulation by IL-10. The induction of IL-10 that occurs after LPS production has been proposed to be a cell-autonomous means of controlling macrophage glycolytic activity (6). While these studies have shown IL-10 produced by M1 macrophages has a role in modulating the metabolic reprogramming toward glycolysis, a question of interest is whether the paracrine production of IL-10 by M2 macrophages within a mixed population is also capable of modulating the metabolic activity of glycolytic M1 macrophages. Whether metabolic reprogramming occurs only within the cell itself, or whether it can be driven by the activation profile of other cells locally within tissue is an open question that has great impact on the therapeutic potential of these recent findings.

\section{Carbohydrate Kinase-Like Protein}

The association of metabolism with macrophage phenotype is underlined by the ability of an unbiased screen for regulators of macrophage function to select a novel metabolic regulator. A kinase screen of 199 human kinase sequences in the RAW264.7 macrophage cell line to identify kinases altering TNF- $\alpha$ production identified carbohydrate kinase-like protein (CARKL) alongside known regulators such as p38 (37). Despite being screened for cytokine production, the gene identified is an orphan receptor in the pentose phosphate pathway. LPS treatment was shown to downregulate CARKL expression, but in the presence of plasmid-derived overexpression, production of "proinflammatory" cytokines including IL- 6 and TNF- $\alpha$ was blunted, whereas expression of IL-10 was augmented (37). Knock down of CARKL produced changes within the macrophage cell line that mirrored LPS activation-namely the switch toward glycolysis; in the presence of LPS these cells demonstrated additional expression of TNF- $\alpha$ and IL- 6 expression, indicating that CARKL loss is sufficient to at least, in part, mimic an M1-like macrophage phenotype (37). The regulation of CARKL by M1 and M2 stimuli is reciprocal as treatment of cells with M2 stimuli causes an upregulation of CARKL, indicating it has roles across multiple macrophage phenotypes, and interventions into CARKL function may have the ability to mediate macrophage metabolic reprogramming (37).

\section{IL-4}

How far it is possible to reprogram individual macrophages versus the pool of macrophages present in the tissue as a whole is an important question when considering disease interventions. Do you need to replace the pool of cells present, or can the phenotype of the existing cells present be 
modulated. Certainly driving quiescent macrophages to either M1 or M2 phenotype is well described, but once committed to one of these phenotypes, how far can their phenotype now be modulated? In particular, can cells switch away from the M1-driven glycolytic metabolism once polarized? Rechallenging either mouse or human macrophages with IL-4 after previously polarizing them with M1 stimuli demonstrated that the IL-4 rechallenge did not cause the cells to express either marker genes (including $\mathrm{Mrcl}$ or Fizzlmouse, CCL22, CD206, or CCL24 human) or cell surface markers such as CD206 (mouse and human) (97). When cellular metabolism was assessed, the prior switching of macrophage metabolism to glycolysis and suppression of OXPHOS was not reversed when the cells were then restimulated with IL-4, indicating that they were metabolically trapped (97). The induction of iNOS and production of NO by M1 macrophages is a key feature of M1 macrophages; inhibition of NO production was shown to improve OXPHOS activity in M1 macrophages and to allow at least partial repolarization to an M2 phenotype as measured by cell surface marker expression (97). This study underlines, through the ability of iNOS modulation to alter macrophage metabolic and phenotypic polarization, that as we understand more about macrophage metabolism, the interplay of different cellular processes may unveil novel pathways for metabolic reprogramming.

\section{Mammalian Target of Rapamycin}

The mammalian target of rapamycin (mTOR), a serine/ threonine kinase, is involved in wide biological processes such as regulation of cell growth, proliferation, nutrient transport, and sensing environmental signals such as insulin, glucose, and amino acids (99). Macrophage-specific deletion of mechanistic target of rapamycin complex 1 (mTORC1) protects HFD-fed mice by reducing inflammation through inactivation of Akt and reducing IR by inhibiting the $1 \alpha /$ clun NH2-terminal kinase-nuclear factor kappa-light-chainenhancer of activated B cells (IRE1 $\alpha / \mathrm{JNK} / \mathrm{NF}-\kappa \mathrm{B}$ ) pathway (49). Pharmacological inhibition of mTORC1 with rapamycin in HFD-fed mice worsened glucose intolerance and AT inflammation by increasing the number of polarized M1 macrophages, naive and activated cytotoxic T lymphocytes, and proinflammatory markers such as TNF- $\alpha$, IL-6, and MCP-1. Moreover, inhibition of mTORC1 and mTORC2 with torin 1 promoted M1 macrophage polarization in BMDMs (83). The tuberous sclerosis complex comprising 1 (Tsc1) deficiency in BMDMs exhibits increase in production of proinflammatory cytokines, activates mTORC1, and reduces IL-10 expression. Moreover, BMDMs deficient in Tsc 1 exhibit decrease in M2 macrophage markers (Arg-1, Fizz1, macrophage galactose-type lectin-1 [Mgl1/CD301] and 2, Ym-1, and PGC-1 $\beta$ ). Tsc1-deficient BMDMs treated with IL4 exhibit mTORC1-mediated decrease in Akt activation that contributes to defect in M2 macrophage polarization (13, 83). These strong impacts on macrophage polarization imply that immunometabolism may be altered by targeting the mTOR pathway and indeed Tsc-1-deficient BMDMs show no increase in FAO in response to IL-4 stimulation (13). The seemingly contradictory finding that both inhibition of mTORC1-promoting M1 differentiation and activation of mTORC1, by Tsc1 deletion, decreasing M2 polarization, indicates that there is more we need to understand about regulation of this pathway under both physiological and pathophysiological conditions. The mTORC 2 complex is required for M2 macrophage polarization, with loss of the defining complex subunit Rictor preventing increased OXPHOS utilization after IL-4 stimulation and reducing expression of characteristic M2 genes (43). These new links of the mTOR pathway to macrophage metabolism, given the existing association of this pathway with AT biology, make this a very relevant pathway for study in ATMs.

\section{Future Questions and Challenges}

The striking changes in macrophage metabolism that occur with differential polarization have opened up an exciting new area for research in metabolic diseases. We have highlighted here some of the key mediators within the cell that act as modulators of macrophage metabolic function. Much of the fundamental analysis of macrophage metabolism has been performed in mouse models and in vitro derived or activated cells, which allows development of a defined system of homogenously polarized cells. However, in vivo macrophage phenotypes are rarely so clear. Defining the metabolic profile of primary macrophages isolated from in vivo tissues is a crucial next step for this field. Although AT and ATM show elements of an M2 to M1 switch with obesity, the precise phenotype of these cells will be unique to their local environment. For example, ATM populations have been shown to contain lysosome-rich and lipid-laden cells (109). These ATM features, and other phenotypic changes caused by obesity, diabetes, and other metabolic conditions, are likely to be manifest in their metabolic profile, as it is their cytokine output and gene expression.

As we begin to understand how far macrophage metabolism may define the phenotype of activated cells, it will become apparent how far other cellular functions that may be beneficial or drive disease can be altered by targeting cellular metabolism. Can we target macrophage metabolism to within AT to modulate their inflammatory phenotype in obese or diabetic individuals? Is there scope to fundamentally alter the phenotype of the cells to an anti-inflammatory phenotype that might actively contribute to resolving disease, rather than just reducing inflammatory signaling? Is immunometabolism a target for AT "hyperglycemic memory," whereby previous IR or diabetes confers long-term adverse effects on metabolism and cardiovascular risk, even when glycemic control is achieved and maintained? Whereas epigenetic changes related to diabetic complications in "end organ" cells (e.g., renal, endothelial, neuronal, and smooth muscle cells) are well described, the importance of "metabolic memory" in immune cells in AT will be important to investigate. Some initial experimental evidence already indicates an important role for epigenetic regulation of macrophage differentiation. In ATM of obese (ob/ob) mice, expression of the DNA methyltransferases DNMT1 is reduced in M2 macrophages compared with that in M1 macrophages. Inhibition of DNMT1 in ob/ob mice, either by pharmacological agent 5aza-2'-deoxycytidine or by myeloid-specific deletion of DNMT1, promotes M2 macrophage differentiation by decreasing the PPAR- $\gamma 1$ promoter DNA methylation (101). But are genes that encode or regulate macrophage metabolism targets for epigenetic modification? 
The ability of cell surface nutrient uptake receptors such as GLUT1 to alter macrophage metabolism hints that nutrient availability locally, and potentially systemically in the case of metabolic disease, may alter macrophage phenotype. This could reveal a mechanism by which interventions not directly targeting macrophages may in fact have potent effects on macrophage metabolism. For example, interventions such as exercise training could have important effects on AT inflammation, beyond weight loss. For example, in obese mice, exercise training reduced macrophage clusters in AT and increased the number of $\mathrm{CD}^{+} \mathrm{T}$ cells $(53)$. Exercise training in HFD-fed mice also inhibits AT inflammation by inhibiting TNF- $\alpha$, TLR4, the number of F4/80 macrophages, and CD11 ${ }^{+}$cells (an M1 macrophage marker), whereas CD163 ${ }^{+}$ cells (an M2 macrophage marker) are decreased (60). This suggests that exercise training might induce a phenotypic switch of M1 macrophages to M2 macrophages in AT (47, 52). Revisiting these findings now we understand that the importance of macrophage metabolic reprogramming would provide insight into whether existing interventions to combat obesity are altering AT biology at the level macrophage metabolism. As our knowledge of macrophage metabolic programming in AT builds, there will be increasing scope for targeting this aspect of macrophage biology as a therapeutic strategy in metabolic diseases.

\section{Acknowledgments}

This work was supported by the British Heart Foundation (RG/15/10/31485 and RG/12/5/29576), the Wellcome Trust (090532/Z/09/Z), by the Tripartite Immunometabolism Consortium [TrIC]- Novo Nordisk Foundation (NNF15CC0018486), and by the National Institute for Health Research (NIHR) Oxford Biomedical Research Centre.

\section{References}

1. Amano SU, Cohen JL, Vangala P, Tencerova M, Nicoloro SM, Yawe JC, Shen Y, Czech MP, and Aouadi M. Local proliferation of macrophages contributes to obesity-associated adipose tissue inflammation. Cell Metab 19: 162-171, 2014.

2. Andersson ER, Sandberg R, and Lendahl U. Notch signaling: simplicity in design, versatility in function. Development 138: 3593-3612, 2011.

3. Arner P. The adipocyte in insulin resistance: key molecules and the impact of the thiazolidinediones. Trends Endocrinol Metab 14: 137-145, 2003.

4. Aronoff SL, Berkowitz K, Shreiner B, and Want L. Glucose metabolism and regulation: beyond insulin and glucagon. Diabetes Spectrum 17: 183-190, 2004.

5. Bartelt A, Bruns OT, Reimer R, Hohenberg H, Ittrich H, Peldschus K, Kaul MG, Tromsdorf UI, Weller H, Waurisch C, Eychmuller A, Gordts PL, Rinninger F, Bruegelmann K, Freund B, Nielsen P, Merkel M, and Heeren J. Brown adipose tissue activity controls triglyceride clearance. Nat Med 17: 200-205, 2011.

6. Baseler WA, Davies LC, Quigley L, Ridnour LA, Weiss JM, Hussain SP, Wink DA, and McVicar DW. Autocrine IL-10 functions as a rheostat for M1 macrophage glycolytic commitment by tuning nitric oxide production. Redox Biol 10: 12-23, 2016.

7. Bechmann LP, Hannivoort RA, Gerken G, Hotamisligil GS, Trauner M, and Canbay A. The interaction of hepatic lipid and glucose metabolism in liver diseases. $J$ Hepatol 56: 952-964, 2012.

8. Bi $\mathrm{P}$ and Kuang $\mathrm{S}$. Notch signaling as a novel regulator of metabolism. Trends Endocrinol Metab 26: 248-255, 2015.

9. Bi P, Shan T, Liu W, Yue F, Yang X, Liang XR, Wang J, Li J, Carlesso N, Liu X, and Kuang S. Inhibition of Notch signaling promotes browning of white adipose tissue and ameliorates obesity. Nat Med 20: 911-918, 2014.

10. Bjorndal B, Burri L, Staalesen V, Skorve J, and Berge RK. Different adipose depots: their role in the development of metabolic syndrome and mitochondrial response to hypolipidemic agents. J Obes 2011: 490650, 2011.

11. Bouhlel MA, Brozek J, Derudas B, Zawadzki C, Jude B, Staels B, and Chinetti-Gbaguidi G. Unlike PPARgamma, PPARalpha or PPARbeta/delta activation does not promote human monocyte differentiation toward alternative macrophages. Biochem Biophys Res Commun 386: 459-462, 2009.

12. Brune B, Dehne N, Grossmann N, Jung M, Namgaladze D, Schmid T, von Knethen A, and Weigert A. Redox control of inflammation in macrophages. Antioxid Redox Signal 19: 595-637, 2013.

13. Byles V, Covarrubias AJ, Ben-Sahra I, Lamming DW, Sabatini DM, Manning BD, and Horng T. The TSCmTOR pathway regulates macrophage polarization. Nat Commun 4: 2834, 2013.

14. Cai D, Yuan M, Frantz DF, Melendez PA, Hansen L, Lee $\mathrm{J}$, and Shoelson SE. Local and systemic insulin resistance resulting from hepatic activation of IKK-beta and NFkappaB. Nat Med 11: 183-190, 2005.

15. Calandra $\mathrm{T}$ and Roger $\mathrm{T}$. Macrophage migration inhibitory factor: a regulator of innate immunity. Nat Rev Immunol 3: 791-800, 2003.

16. Cao H. Adipocytokines in obesity and metabolic disease. $J$ Endocrinol 220: T47-T59, 2014.

17. Caselli C. Role of adiponectin system in insulin resistance. Mol Genet Metab 113: 155-160, 2014.

18. Cullberg KB, Larsen JO, Pedersen SB, and Richelsen B. Effects of LPS and dietary free fatty acids on MCP-1 in 3T3-L1 adipocytes and macrophages in vitro. Nutr Diabetes 4: e113, 2014.

19. Despres JP and Lemieux I. Abdominal obesity and metabolic syndrome. Nature 444: 881-887, 2006.

20. Dresner A, Laurent D, Marcucci M, Griffin ME, Dufour S, Cline GW, Slezak LA, Andersen DK, Hundal RS, Rothman DL, Petersen KF, and Shulman GI. Effects of free fatty acids on glucose transport and IRS-1-associated phosphatidylinositol 3-kinase activity. J Clin Invest 103: 253-259, 1999.

21. Fernández-Veledo S, Nieto-Vazquez I, Rondinone CM, and Lorenzo M. Liver $\mathrm{X}$ receptor agonists ameliorate $\mathrm{TNF} \alpha$-induced insulin resistance in murine brown adipocytes by downregulating protein tyrosine phosphatase-1B gene expression. Diabetologia 49: 3038, 2006.

22. Ferrante AW Jr. Obesity-induced inflammation: a metabolic dialogue in the language of inflammation. $J$ Intern Med 262: 408-414, 2007.

23. Finucane OM, Reynolds CM, McGillicuddy FC, Harford KA, Morrison M, Baugh J, and Roche HM. Macrophage migration inhibitory factor deficiency ameliorates high-fat diet induced insulin resistance in mice with reduced adipose inflammation and hepatic steatosis. PLoS One 9: e113369, 2014.

24. Finucane OM, Reynolds CM, McGillicuddy FC, and Roche HM. Insights into the role of macrophage migration 
inhibitory factor in obesity and insulin resistance. Proc Nutr Soc 71: 622-633, 2012.

25. Franssens BT, van der Graaf Y, Kappelle LJ, Westerink J, de Borst GJ, Cramer MJ, and Visseren FL. Body weight, metabolic dysfunction, and risk of type 2 diabetes in patients at high risk for cardiovascular events or with manifest cardiovascular disease: a cohort study. Diabetes Care 38: 1945-1951, 2015.

26. Franssens BT, Westerink J, van der Graaf Y, Nathoe HM, and Visseren FL. Metabolic consequences of adipose tissue dysfunction and not adiposity per se increase the risk of cardiovascular events and mortality in patients with type 2 diabetes. Int J Cardiol 222: 72-77, 2016.

27. Freemerman AJ, Johnson AR, Sacks GN, Milner JJ, Kirk EL, Troester MA, Macintyre AN, Goraksha-Hicks P, Rathmell JC, and Makowski L. Metabolic reprogramming of macrophages: glucose transporter 1 (GLUT1)-mediated glucose metabolism drives a proinflammatory phenotype. J Biol Chem 289: 7884-7896, 2014.

28. Furukawa S, Fujita T, Shimabukuro M, Iwaki M, Yamada Y, Nakajima Y, Nakayama O, Makishima M, Matsuda M, and Shimomura I. Increased oxidative stress in obesity and its impact on metabolic syndrome. J Clin Invest 114: 1752-1761, 2004.

29. Garces C, Ruiz-Hidalgo MJ, Font de Mora J, Park C, Miele L, Goldstein J, Bonvini E, Porras A, and Laborda J. Notch-1 controls the expression of fatty acid-activated transcription factors and is required for adipogenesis. $J$ Biol Chem 272: 29729-29734, 1997.

30. Garg SK, Delaney C, Shi H, and Yung R. Changes in adipose tissue macrophages and $\mathrm{T}$ cells during aging. Crit Rev Immunol 34: 1-14, 2014.

31. Gericke M, Weyer U, Braune J, Bechmann I, and Eilers J. A method for long-term live imaging of tissue macrophages in adipose tissue explants. Am J Physiol Endocrinol Metab 308: E1023-E1033, 2015.

32. Ghanim H, Aljada A, Hofmeyer D, Syed T, Mohanty P, and Dandona P. Circulating mononuclear cells in the obese are in a proinflammatory state. Circulation 110: 1564-1571, 2004.

33. Gordon S. Alternative activation of macrophages. Nat Rev Immunol 3: 23-35, 2003.

34. Han CY, Umemoto T, Omer M, Den Hartigh LJ, Chiba T, LeBoeuf R, Buller CL, Sweet IR, Pennathur S, Abel ED, and Chait A. NADPH oxidase-derived reactive oxygen species increases expression of monocyte chemotactic factor genes in cultured adipocytes. J Biol Chem 287: 10379-10393, 2012.

35. Han MS, Jung DY, Morel C, Lakhani SA, Kim JK, Flavell RA, and Davis RJ. JNK expression by macrophages promotes obesity-induced insulin resistance and inflammation. Science 339: 218-222, 2013.

36. Harms $M$ and Seale P. Brown and beige fat: development, function and therapeutic potential. Nat Med 19: 1252-1263, 2013.

37. Haschemi A, Kosma P, Gille L, Evans CR, Burant CF, Starkl P, Knapp B, Haas R, Schmid JA, Jandl C, Amir S, Lubec G, Park J, Esterbauer H, Bilban M, Brizuela L, Pospisilik JA, Otterbein LE, and Wagner O. The sedoheptulose kinase CARKL directs macrophage polarization through control of glucose metabolism. Cell Metab 15: 813-826, 2012.

38. Hernandez EA, Kahl S, Seelig A, Begovatz P, Irmler M, Kupriyanova Y, Nowotny B, Nowotny P, Herder C, Barosa
C, Carvalho F, Rozman J, Neschen S, Jones JG, Beckers J, de Angelis MH, and Roden M. Acute dietary fat intake initiates alterations in energy metabolism and insulin resistance. J Clin Invest 127: 695-708, 2017.

39. Holzer RG, Park EJ, Li N, Tran H, Chen M, Choi C, Solinas G, and Karin M. Saturated fatty acids induce c-Src clustering within membrane subdomains, leading to JNK activation. Cell 147: 173-184, 2011.

40. Hotamisligil GS. Inflammation, metaflammation and immunometabolic disorders. Nature 542: 177-185, 2017.

41. Hotamisligil GS, Shargill NS, and Spiegelman BM. Adipose expression of tumor necrosis factor-alpha: direct role in obesity-linked insulin resistance. Science 259: 87-91, 1993.

42. Huang SC, Everts B, Ivanova Y, O'Sullivan D, Nascimento M, Smith AM, Beatty W, Love-Gregory L, Lam WY, O'Neill CM, Yan C, Du H, Abumrad NA, Urban JF, Jr., Artyomov MN, Pearce EL, and Pearce EJ. Cell-intrinsic lysosomal lipolysis is essential for alternative activation of macrophages. Nat Immunol 15: 846-855, 2014.

43. Huang SC, Smith AM, Everts B, Colonna M, Pearce EL, Schilling JD, and Pearce EJ. Metabolic reprogramming mediated by the mTORC2-IRF4 signaling axis is essential for macrophage alternative activation. Immunity 45: 817830, 2016.

44. Ichimura A, Hasegawa S, Kasubuchi M, and Kimura I. Free fatty acid receptors as therapeutic targets for the treatment of diabetes. Front Pharmacol 5: 236, 2014.

45. Ip WKE, Hoshi N, Shouval DS, Snapper S, and Medzhitov R. Anti-inflammatory effect of IL-10 mediated by metabolic reprogramming of macrophages. Science 356: 513-519, 2017.

46. Jang JE, Ko MS, Yun JY, Kim MO, Kim JH, Park HS, Kim AR, Kim HJ, Kim BJ, Ahn YE, Oh JS, Lee WJ, Harris RA, $\mathrm{Koh} \mathrm{EH}$, and Lee KU. Nitric oxide produced by macrophages inhibits adipocyte differentiation and promotes profibrogenic responses in preadipocytes to induce adipose tissue fibrosis. Diabetes 65: 2516-2528, 2016.

47. Jeong JH, Lee YR, Park HG, and Lee WL. The effects of either resveratrol or exercise on macrophage infiltration and switching from M1 to M2 in high fat diet mice. J Exerc Nutr Biochem 19: 65-72, 2015.

48. Jha AK, Huang SC, Sergushichev A, Lampropoulou V, Ivanova Y, Loginicheva E, Chmielewski K, Stewart KM, Ashall J, Everts B, Pearce EJ, Driggers EM, and Artyomov MN. Network integration of parallel metabolic and transcriptional data reveals metabolic modules that regulate macrophage polarization. Immunity 42: 419-430, 2015.

49. Jiang $\mathrm{H}$, Westerterp $\mathrm{M}$, Wang $\mathrm{C}$, Zhu $\mathrm{Y}$, and Ai D. Macrophage mTORC1 disruption reduces inflammation and insulin resistance in obese mice. Diabetologia 57: 2393-2404, 2014.

50. Johnson AR, Qin Y, Cozzo AJ, Freemerman AJ, Huang MJ, Zhao L, Sampey BP, Milner JJ, Beck MA, Damania B, Rashid N, Galanko JA, Lee DP, Edin ML, Zeldin DC, Fueger PT, Dietz B, Stahl A, Wu Y, Mohlke KL, and Makowski L. Metabolic reprogramming through fatty acid transport protein 1 (FATP1) regulates macrophage inflammatory potential and adipose inflammation. $\mathrm{Mol}$ Metab 5: 506-526, 2016.

51. Katsuki A, Sumida Y, Murashima S, Murata K, Takarada Y, Ito K, Fujii M, Tsuchihashi K, Goto H, Nakatani K, and Yano Y. Serum levels of tumor necrosis factor-alpha are increased in obese patients with noninsulin-dependent diabetes mellitus. J Clin Endocrinol Metab 83: 859-862, 1998. 
52. Kawanishi N, Yano H, Yokogawa Y, and Suzuki K. Exercise training inhibits inflammation in adipose tissue via both suppression of macrophage infiltration and acceleration of phenotypic switching from M1 to M2 macrophages in high-fat-diet-induced obese mice. Exerc Immunol Rev 16: 105-118, 2010.

53. Kawanishi N, Mizokami T, Yano H, and Suzuki K. Exercise attenuates M1 macrophages and CD8+ T cells in the adipose tissue of obese mice. Med Sci Sports Exerc 45: 1684-1693, 2013.

54. Kelly B and O'Neill LA. Metabolic reprogramming in macrophages and dendritic cells in innate immunity. Cell Res 25: 771-784, 2015.

55. Kopan R and Ilagan MX. The canonical Notch signaling pathway: unfolding the activation mechanism. Cell 137: 216-233, 2009.

56. Kuczmarski RJ, Flegal KM, Campbell SM, and Johnson CL. Increasing prevalence of overweight among US adults. The National Health and Nutrition Examination Surveys, 1960 to 1991. JAMA 272: 205-211, 1994.

57. Lee BC and Lee J. Cellular and molecular players in adipose tissue inflammation in the development of obesityinduced insulin resistance. Biochim Biophys Acta 1842: 446-462, 2014.

58. Lumeng CN, Bodzin JL, and Saltiel AR. Obesity induces a phenotypic switch in adipose tissue macrophage polarization. J Clin Invest 117: 175-184, 2007.

59. MacPherson RE, Gamu D, Frendo-Cumbo S, Castellani L, Kwon F, Tupling AR, and Wright DC. Sarcolipin knockout mice fed a high-fat diet exhibit altered indices of adipose tissue inflammation and remodeling. Obesity (Silver Spring) 24: 1499-1505, 2016.

60. Macpherson RE, Huber JS, Frendo-Cumbo S, Simpson JA, and Wright DC. Adipose tissue insulin action and IL-6 signaling after exercise in obese mice. Med Sci Sports Exerc 47: 2034-2042, 2015.

61. Magkos F, Fraterrigo G, Yoshino J, Luecking C, Kirbach K, Kelly SC, de Las Fuentes L, He S, Okunade AL, Patterson BW, and Klein S. Effects of moderate and subsequent progressive weight loss on metabolic function and adipose tissue biology in humans with obesity. Cell Metab 23: 591-601, 2016.

62. Majumder S, Zhu G, Xu X, Senchanthisai S, Jiang D, Liu H, Xue C, Wang X, Coia H, Cui Z, Smolock EM, Libby RT, Berk BC, and Pang J. G-protein-coupled receptor-2interacting protein-1 controls stalk cell fate by inhibiting delta-like 4-Notch1 signaling. Cell Rep 17: 2532-2541, 2016.

63. Malandrino MI, Fucho R, Weber M, Calderon-Dominguez M, Mir JF, Valcarcel L, Escote X, Gomez-Serrano M, Peral B, Salvado L, Fernandez-Veledo S, Casals N, VazquezCarrera M, Villarroya F, Vendrell JJ, Serra D, and Herrero L. Enhanced fatty acid oxidation in adipocytes and macrophages reduces lipid-induced triglyceride accumulation and inflammation. Am J Physiol Endocrinol Metab 308: E756-E769, 2015.

64. Mantovani A, Sica A, Sozzani S, Allavena P, Vecchi A, and Locati M. The chemokine system in diverse forms of macrophage activation and polarization. Trends Immunol 25: 677-686, 2004.

65. Martinez FO and Gordon S. The M1 and M2 paradigm of macrophage activation: time for reassessment. F1000Prime Rep 6: 13, 2014.
66. Martinez FO, Sica A, Mantovani A, and Locati M. Macrophage activation and polarization. Front Biosci 13: 453461, 2008.

67. McMurray F, Patten DA, and Harper ME. Reactive oxygen species and oxidative stress in obesity-recent findings and empirical approaches. Obesity (Silver Spring) 24: 2301-2310, 2016.

68. McNelis JC and Olefsky JM. Macrophages, immunity, and metabolic disease. Immunity 41: 36-48, 2014.

69. Miller AM, Asquith DL, Hueber AJ, Anderson LA, Holmes WM, McKenzie AN, Xu D, Sattar N, McInnes IB, and Liew FY. Interleukin-33 induces protective effects in adipose tissue inflammation during obesity in mice. Circ Res 107: 650-658, 2010.

70. Monsalve E, Ruiz-Garcia A, Baladron V, Ruiz-Hidalgo MJ, Sanchez-Solana B, Rivero S, Garcia-Ramirez JJ, Rubio A, Laborda J, and Diaz-Guerra MJ. Notch1 upregulates LPS-induced macrophage activation by increasing NF-kappaB activity. Eur J Immunol 39: 2556-2570, 2009.

71. Mothe-Satney I, Filloux C, Amghar H, Pons C, Bourlier V, Galitzky J, Grimaldi PA, Feral CC, Bouloumie A, Van Obberghen E, and Neels JG. Adipocytes secrete leukotrienes: contribution to obesity-associated inflammation and insulin resistance in mice. Diabetes 61: 2311-2319, 2012.

72. Nishikawa T and Araki E. Impact of mitochondrial ROS production in the pathogenesis of diabetes mellitus and its complications. Antioxid Redox Signal 9: 343-353, 2007.

73. Nishimura S, Manabe I, Nagasaki M, Eto K, Yamashita H, Ohsugi M, Otsu M, Hara K, Ueki K, Sugiura S, Yoshimura K, Kadowaki T, and Nagai R. CD8+ effector T cells contribute to macrophage recruitment and adipose tissue inflammation in obesity. Nat Med 15: 914-920, 2009.

74. Nishizawa T, Kanter JE, Kramer F, Barnhart S, Shen X, Vivekanandan-Giri A, Wall VZ, Kowitz J, Devaraj S, O'Brien KD, Pennathur S, Tang J, Miyaoka RS, Raines $\mathrm{EW}$, and Bornfeldt KE. Testing the role of myeloid cell glucose flux in inflammation and atherosclerosis. Cell Rep 7: 356-365, 2014.

75. Nomura M, Liu J, Rovira, II, Gonzalez-Hurtado E, Lee J, Wolfgang MJ, and Finkel T. Fatty acid oxidation in macrophage polarization. Nat Immunol 17: 216-217, 2016.

76. Odegaard JI and Chawla A. Alternative macrophage activation and metabolism. Annu Rev Pathol 6: 275-297, 2011.

77. Odegaard JI, Ricardo-Gonzalez RR, Red Eagle A, Vats D, Morel CR, Goforth MH, Subramanian V, Mukundan L, Ferrante AW, and Chawla A. Alternative M2 activation of Kupffer cells by PPARdelta ameliorates obesity-induced insulin resistance. Cell Metab 7: 496-507, 2008.

78. Olefsky JM and Glass CK. Macrophages, inflammation, and insulin resistance. Annu Rev Physiol 72: 219-246, 2010.

79. Ouchi N, Higuchi A, Ohashi K, Oshima Y, Gokce N, Shibata R, Akasaki Y, Shimono A, and Walsh K. Sfrp5 is an anti-inflammatory adipokine that modulates metabolic dysfunction in obesity. Science 329: 454-457, 2010.

80. Pajvani UB, Shawber CJ, Samuel VT, Birkenfeld AL, Shulman GI, Kitajewski J, and Accili D. Inhibition of Notch signaling ameliorates insulin resistance in a FoxO1dependent manner. Nat Med 17: 961-967, 2011.

81. Palsson-McDermott EM, Curtis AM, Goel G, Lauterbach MA, Sheedy FJ, Gleeson LE, van den Bosch MW, Quinn SR, Domingo-Fernandez R, Johnston DG, Jiang JK, Israelsen WJ, Keane J, Thomas C, Clish C, Vander Heiden M, Xavier RJ, and O'Neill LA. Pyruvate kinase M2 regulates Hif-1alpha activity and IL-1beta induction and is a 
critical determinant of the warburg effect in LPS-activated macrophages. Cell Metab 21: 65-80, 2015.

82. Palsson-McDermott EM, and O'Neill LA. The Warburg effect then and now: from cancer to inflammatory diseases. Bioessays 35: 965-973, 2013.

83. Paschoal VA, Amano MT, Belchior T, Magdalon J, Chimin $\mathrm{P}$, Andrade ML, Ortiz-Silva M, Castro E, Yamashita AS, Rosa Neto JC, Camara NO, and Festuccia WT. mTORC1 inhibition with rapamycin exacerbates adipose tissue inflammation in obese mice and dissociates macrophage phenotype from function. Immunobiology 222: 261-271, 2017.

84. Philipsen A, Jorgensen ME, Vistisen D, Sandbaek A, Almdal TP, Christiansen JS, Lauritzen T, and Witte DR. Associations between ultrasound measures of abdominal fat distribution and indices of glucose metabolism in a population at high risk of type 2 diabetes: the ADDITIONPRO study. PLoS One 10: e0123062, 2015.

85. Roden M, Price TB, Perseghin G, Petersen KF, Rothman DL, Cline GW, and Shulman GI. Mechanism of free fatty acid-induced insulin resistance in humans. J Clin Invest 97: 2859-2865, 1996.

86. Romacho T, Elsen M, Rohrborn D, and Eckel J. Adipose tissue and its role in organ crosstalk. Acta Physiol (Oxf) 210: 733-753, 2014.

87. Romeo GR, Lee J, and Shoelson SE. Metabolic syndrome, insulin resistance, and roles of inflammation-mechanisms and therapeutic targets. Arterioscler Thromb Vasc Biol 32: 1771-1776, 2012.

88. Rosen ED and Spiegelman BM. Adipocytes as regulators of energy balance and glucose homeostasis. Nature 444: $847-853,2006$

89. Rot A and von Andrian UH. Chemokines in innate and adaptive host defense: basic chemokinese grammar for immune cells. Annu Rev Immunol 22: 891-928, 2004.

90. Samaan MC, Marcinko K, Sikkema S, Fullerton MD, Ziafazeli T, Khan MI, and Steinberg GR. Endurance interval training in obese mice reduces muscle inflammation and macrophage content independently of weight loss. Physiol Rep 2, 2014.

91. Satoh M, Hoshino M, Fujita K, Iizuka M, Fujii S, Clingan CS, Van Kaer L, and Iwabuchi K. Adipocyte-specific CD1d-deficiency mitigates diet-induced obesity and insulin resistance in mice. Sci Rep 6: 28473, 2016.

92. Satoh $\mathrm{M}$ and Iwabuchi K. Communication between natural killer T cells and adipocytes in obesity. Adipocyte 5: 389-393, 2016.

93. Shi H, Kokoeva MV, Inouye K, Tzameli I, Yin H, and Flier JS. TLR4 links innate immunity and fatty acid-induced insulin resistance. J Clin Invest 116: 3015-3025, 2006.

94. Suganami T, Nishida J, and Ogawa Y. A paracrine loop between adipocytes and macrophages aggravates inflammatory changes: role of free fatty acids and tumor necrosis factor alpha. Arterioscler Thromb Vasc Biol 25: 20622068, 2005.

95. Talior I, Tennenbaum T, Kuroki T, and Eldar-Finkelman $\mathrm{H}$. PKC-delta-dependent activation of oxidative stress in adipocytes of obese and insulin-resistant mice: role for NADPH oxidase. Am J Physiol Endocrinol Metab 288: E405-E411, 2005.

96. Talukdar S, Oh DY, Bandyopadhyay G, Li D, Xu J, McNelis J, Lu M, Li P, Yan Q, Zhu Y, Ofrecio J, Lin M, Brenner MB, and Olefsky JM. Neutrophils mediate insulin resistance in mice fed a high-fat diet through secreted elastase. Nat Med 18: 1407-1412, 2012.
97. Van den Bossche J, Baardman J, Otto NA, van der Velden $\mathrm{S}$, Neele AE, van den Berg SM, Luque-Martin R, Chen HJ, Boshuizen MC, Ahmed M, Hoeksema MA, de Vos $\mathrm{AF}$, and de Winther MP. Mitochondrial dysfunction prevents repolarization of inflammatory macrophages. Cell Rep 17: 684-696, 2016.

98. Vats D, Mukundan L, Odegaard JI, Zhang L, Smith KL, Morel CR, Wagner RA, Greaves DR, Murray PJ, and Chawla A. Oxidative metabolism and PGC-1beta attenuate macrophage-mediated inflammation. Cell Metab 4: 13-24, 2006.

99. Veilleux A, Houde VP, Bellmann K, and Marette A. Chronic inhibition of the mTORC1/S6K1 pathway increases insulin-induced PI3K activity but inhibits Akt2 and glucose transport stimulation in 3T3-L1 adipocytes. Mol Endocrinol 24: 766-778, 2010.

100. Wang P, Mariman E, Renes J, and Keijer J. The secretory function of adipocytes in the physiology of white adipose tissue. J Cell Physiol 216: 3-13, 2008.

101. Wang X, Cao Q, Yu L, Shi H, Xue B, and Shi H. Epigenetic regulation of macrophage polarization and inflammation by DNA methylation in obesity. JCI Insight 1: e87748, 2016.

102. Wei X, Song H, Yin L, Rizzo MG, Sidhu R, Covey DF, Ory DS, and Semenkovich CF. Fatty acid synthesis configures the plasma membrane for inflammation in diabetes. Nature 539: 294-298, 2016.

103. Weisberg SP, McCann D, Desai M, Rosenbaum M, Leibel RL, and Ferrante AW Jr. Obesity is associated with macrophage accumulation in adipose tissue. J Clin Invest 112: 1796-1808, 2003.

104. West AP, Brodsky IE, Rahner C, Woo DK, ErdjumentBromage H, Tempst P, Walsh MC, Choi Y, Shadel GS, and Ghosh S. TLR signalling augments macrophage bactericidal activity through mitochondrial ROS. Nature 472: 476-480, 2011.

105. Wood IS, Wang B, and Trayhurn P. IL-33, a recently identified interleukin-1 gene family member, is expressed in human adipocytes. Biochem Biophys Res Commun 384: 105-109, 2009.

106. Xu H, Barnes GT, Yang Q, Tan G, Yang D, Chou CJ, Sole J, Nichols A, Ross JS, Tartaglia LA, and Chen H. Chronic inflammation in fat plays a crucial role in the development of obesity-related insulin resistance. J Clin Invest 112: 1821-1830, 2003.

107. Xu H, Zhu J, Smith S, Foldi J, Zhao B, Chung AY, Outtz H, Kitajewski J, Shi C, Weber S, Saftig P, Li Y, Ozato K, Blobel CP, Ivashkiv LB, and Hu X. Notch-RBP-J signaling regulates the transcription factor IRF8 to promote inflammatory macrophage polarization. Nat Immunol 13: 642-650, 2012.

108. Xu J, Chi F, Guo T, Punj V, Lee WN, French SW, and Tsukamoto $\mathrm{H}$. NOTCH reprograms mitochondrial metabolism for proinflammatory macrophage activation. J Clin Invest 125: 1579-1590, 2015.

109. Xu X, Grijalva A, Skowronski A, van Eijk M, Serlie MJ, and Ferrante AW Jr. Obesity activates a program of lysosomal-dependent lipid metabolism in adipose tissue macrophages independently of classic activation. Cell Metab 18: 816-830, 2013.

110. Yu C, Chen Y, Cline GW, Zhang D, Zong H, Wang Y, Bergeron R, Kim JK, Cushman SW, Cooney GJ, Atcheson B, White MF, Kraegen EW, and Shulman GI. Mechanism by which fatty acids inhibit insulin activation of insulin 
receptor substrate-1 (IRS-1)-associated phosphatidylinositol 3-kinase activity in muscle. J Biol Chem 277: 5023050236, 2002.

111. Zhang Y, Mei H, Chang X, Chen F, Zhu Y, and Han X. Adipocyte-derived microvesicles from obese mice induce M1 macrophage phenotype through secreted miR-155. J Mol Cell Biol 8: 505-517, 2016.

112. Zuany-Amorim C, Hastewell J, and Walker C. Toll-like receptors as potential therapeutic targets for multiple diseases. Nat Rev Drug Discov 1: 797-807, 2002.

Address correspondence to:

Prof. Keith M. Channon

Division of Cardiovascular Medicine British Heart Foundation Centre for Research Excellence John Radcliffe Hospital

University of Oxford

Oxford OX3 9DU

United Kingdom

E-mail: keith.channon@cardiov.ox.ac.uk

Date of first submission to ARS Central, March 10, 2017; date of final revised submission, June 23, 2017; date of acceptance, June 23, 2017.

$\begin{aligned} & \text { Abbreviations Used } \\ \mathrm{ASH} & =\text { alcoholic steatohepatitis } \\ \mathrm{AT} & =\text { adipose tissue } \\ \mathrm{ATMs} & =\text { adipose tissue macrophages } \\ \mathrm{BAT} & =\text { brown adipose tissue } \\ \mathrm{BMDS} & =\text { bone marrow-derived macrophages } \\ \mathrm{BMI} & =\text { body mass index } \\ \mathrm{CARKL} & =\text { carbohydrate kinase-like protein } \\ \mathrm{CLSs} & =\text { crown-like structures } \\ \mathrm{CPT} & =\text { carnitine palmitoyltransferase } \\ \mathrm{FA} & =\text { fatty acid } \\ \mathrm{FAO} & =\text { fatty acid oxidation } \\ \mathrm{FATP} 1 & =\text { fatty acid transport protein } 1 \\ \mathrm{FFA} & =\text { free fatty acid } \\ \mathrm{FFAR} & =\text { free fatty acid receptor } \\ \mathrm{FoxO} 1 & =\text { forkhead box protein } \mathrm{O} 1 \\ \mathrm{GLUT} & =\text { glucose transporter }\end{aligned}$

GPCRs $=\mathrm{G}$ protein-coupled receptors $\mathrm{HFD}=$ high-fat diet

HIF- $1 \alpha=$ hypoxia-inducible factor- 1

IFN- $\gamma=$ interferon gamma

IL-6 = interleukin-6

iNOS $=$ inducible NOS

$\mathrm{IR}=$ insulin resistance

IRS- $1=$ insulin receptor substrate- 1

JMJD3 = Jumonji domain-containing 3

$\mathrm{JNK}=$ c-Jun NH2-terminal kinase

LPS $=$ lipopolysaccharide

LTs $=$ leukotrienes

MCP-1 = monocyte chemotactic protein-1

$\mathrm{MIF}=$ macrophage migration inhibitory factor

$\mathrm{mTOR}=$ mammalian target of rapamycin

mTORC1 $=$ mechanistic target of rapamycin complex 1

$\mathrm{NADPH}=$ nicotinamide adenine dinucleotide phosphate

$\mathrm{NF}-\kappa \mathrm{B}=$ nuclear factor-kappaB

$\mathrm{NICD}=$ Notch intracellular domain

$\mathrm{NO}=$ nitric oxide

NOS2 $=$ nitric oxide synthase 2

$\mathrm{PAI}=$ plasminogen activator inhibitor

PGC- $1 \beta=$ PPAR $-\gamma$ coactivator 1-beta

PI3-k = phosphatidylinositol 3-kinase

PKC- $\delta=$ protein kinase C-delta

$\mathrm{PPAR}=$ peroxisome proliferator-activated receptor

$\mathrm{PTP} 1 \mathrm{~B}=$ protein-tyrosine phosphatase 1

$\mathrm{RBP}-\mathrm{J}=$ recombining binding protein suppressor of hairless

ROS $=$ reactive oxygen species

Sfrp5 $=$ secreted frizzled-related protein 5

STAT $=$ signal transducer and activator of transcription

$\mathrm{T} 2 \mathrm{D}=$ type 2 diabetes

$\mathrm{TCA}=$ tricarboxylic acid

$\mathrm{TG}=$ triglyceride

TLR $4=$ toll-like receptor 4

$\mathrm{TNF}-\alpha=$ tumor necrosis factor alpha

Tsc $1=$ tuberous sclerosis complex comprising 1

$\mathrm{UCP} 1=$ uncoupling protein 1

$\mathrm{VAT}=$ visceral AT

$\mathrm{WAT}=$ white adipose tissue 